\title{
Redescription of two subterranean amphipods Niphargus molnari Méhely, 1927 and Niphargus gebhardti Schellenberg, 1934 (Amphipoda, Niphargidae) and their phylogenetic position
}

\author{
Dorottya Angyal ${ }^{1,2}$, Gergely Balázs ${ }^{3}$, Valerija Zakšek ${ }^{4}$ Virág Krízsik ${ }^{5}$ Cene Fišer ${ }^{4}$
}

I Department of Zoology, Hungarian Natural History Museum, Baross u. 13, 1088 Budapest, Hungary

2 Doctoral School of Animal-and Agricultural Environmental Sciences, Department of Animal Sciences and Animal Husbandry, Georgikon Faculty, University of Pannonia, Deák Ferenc u. 16, 8360 Keszthely, Hungary 3 Department of Systematic Zoology and Ecology, Eötvös Loránd University, Pázmány Péter sétány 1/C, 1117 Budapest, Hungary 4 Department of Biology, Biotechnical Faculty, University of Ljubljana, Jamnikarjeva 101, SI-1000 Ljubljana, Slovenia 5 Laboratory of Molecular Taxonomy, Hungarian Natural History Museum, Ludovika tér 2, 1083 Budapest, Hungary

Corresponding author: Dorottya Angyal (angyal.dorottya@gmail.com)

Academic editor: C. O.Coleman | Received 20 April 2015 | Accepted 9 June 2015 | Published 24 June 2015

http://zoobank.org/E48C15FF-9829-447A-93B2-3A8384DCADFF

Citation: Angyal D, Balázs G, Zakšek V, Krízsik V, Fišer C (2015) Redescription of two subterranean amphipods Niphargus molnari Méhely, 1927 and Niphargus gebhardti Schellenberg, 1934 (Amphipoda, Niphargidae) and their phylogenetic position. ZooKeys 509: 53-85. doi: 10.3897/zookeys.509.9820

\begin{abstract}
A detailed redescription of two endemic, cave-dwelling niphargid species of the Hungarian Mecsek Mts., Niphargus molnari Méhely, 1927 and Niphargus gebhardti Schellenberg, 1934 is given based on newly collected material. Morphology was studied under light microscopy and with scanning electon microscopy. Morphological descriptions are complemented with mitochondrial cytochrome c oxidase subunit I (COI) sequences as barcodes for both species and with notes on their ecology. Using three independent molecular markers we showed that $N$. gebhardti belongs to the clade distributed between Central and Eastern Europe, whereas phylogenetic relationship of N. molnari to the rest of Niphargus species is not clear. The two species from the Mecsek Mts. are phylogenetically not closely related. Both species need to be treated as vulnerable according to IUCN Red List of Threatened Species.
\end{abstract}

\section{Keywords}

Hungary, Mecsek Mts., Niphargus, redescription, morphology, phylogeny, endemism, SEM

Copyright Dorottya Angyal et al. This is an open access article distributed under the terms of the Creative Commons Attribution License (CC BY 4.0), which permits unrestricted use, distribution, and reproduction in any medium, provided the original author and source are credited. 


\section{Introduction}

Fragmented mountain areas in East-Central Europe had been suggested to be centres of endemisms that evolved through a complex geological history including Eocene marine regression-transgression cycles and Pleistocene glacial cycles (Hou et al. 2013, Meleg et al. 2013, Mamos et al. 2014). The Mecsek is one of these isolated mountain ranges, that is situated in Southern Hungary and surrounded by Pannonian plains. The closest mountain ranges are the Croatian Papuk Mts. $(80 \mathrm{~km})$ and the Hungarian Transdanubian Mts. (150 km) (Fig. 1). The area is small of approximately $545 \mathrm{~km}^{2}$. In biological sense, it is populated by numerous endemic species the origin of which may date back to Tertiary and which therefore apparently have survived mass extinctions in glacial periods. The upper geological layers comprise of Triassic and Jurassic limestones and dolomites, where extensive karstification has created over 200 caves. The subterranean environment of the area harbours numerous terrestrial and aquatic highly endemic invertebrates, known only from one or a few caves. Although the region apparently harbours an important piece of European and Hungarian natural heritage, until now only one species, the Hungarian blind snail (Bythiospeum hungaricum (Soós, 1927)) has been protected by law. A serious impediment for conservation biology is that our knowledge of species is only limited, beginning with poor taxonomic descriptions. The aim of this study is to bridge this gap at the most basic level. We morphologically redescribe and present phylogenetic relationships of two amphipod species from the genus Niphargus, both endemic to this area.

Niphargus molnari Méhely, 1927 was described from the stream of the Mánfai-kölyuk Cave (Méhely 1927). The description is not detailed, as it contains only a few information about the body lenght, the pereonits, the pleon segments, the first antenna, the uropods and the telson, and two drawings about the epimeral plates and the pereion segments. Further drawing of the right lacinia mobilis can be found in Méhely's summarizing work (Méhely 1941). At approximately the same period the species was also studied by Schellenberg, who analysed samples fom Abaligeti Cave. In his early study he first treated it as $N$. leopoliensis molnari (Schellenberg, 1933), but later he acknowledged its species status and supplemented description with data about the seta number of the palpus of the first maxilla (Schellenberg 1935). The species was found in the Mánfai-kőlyuk Cave (Gebhardt 1933, 1934, 1963, 1967) and in the stream of the Abaligeti Cave too (Gebhardt 1934, 1963, 1967). Recently, the species was found in other two localities, the Spirál Sinkhole and the Vadetetös Sinkhole (Angyal and Balázs 2013). During our research in the caves of the Western Mecsek between 2010 and 2013, the species could not have been re-collected on the type locality, which is supposedly related to the artificial utilization of the Mánfai-kőlyuk Cave. The intrusive introduction of waterworks in the 1960-s and 1970-s has caused irreversible changes in the cave's character, hidrology and ecosystem (Angyal 2012).

Niphargus gebhardti Schellenberg, 1934 was described from the pools formed by dripping water of the Abaligeti Cave, originally as Niphargus foreli gebhardti (Schellenberg 1934). Brief description reports on only few characters, like the pereopods, the 


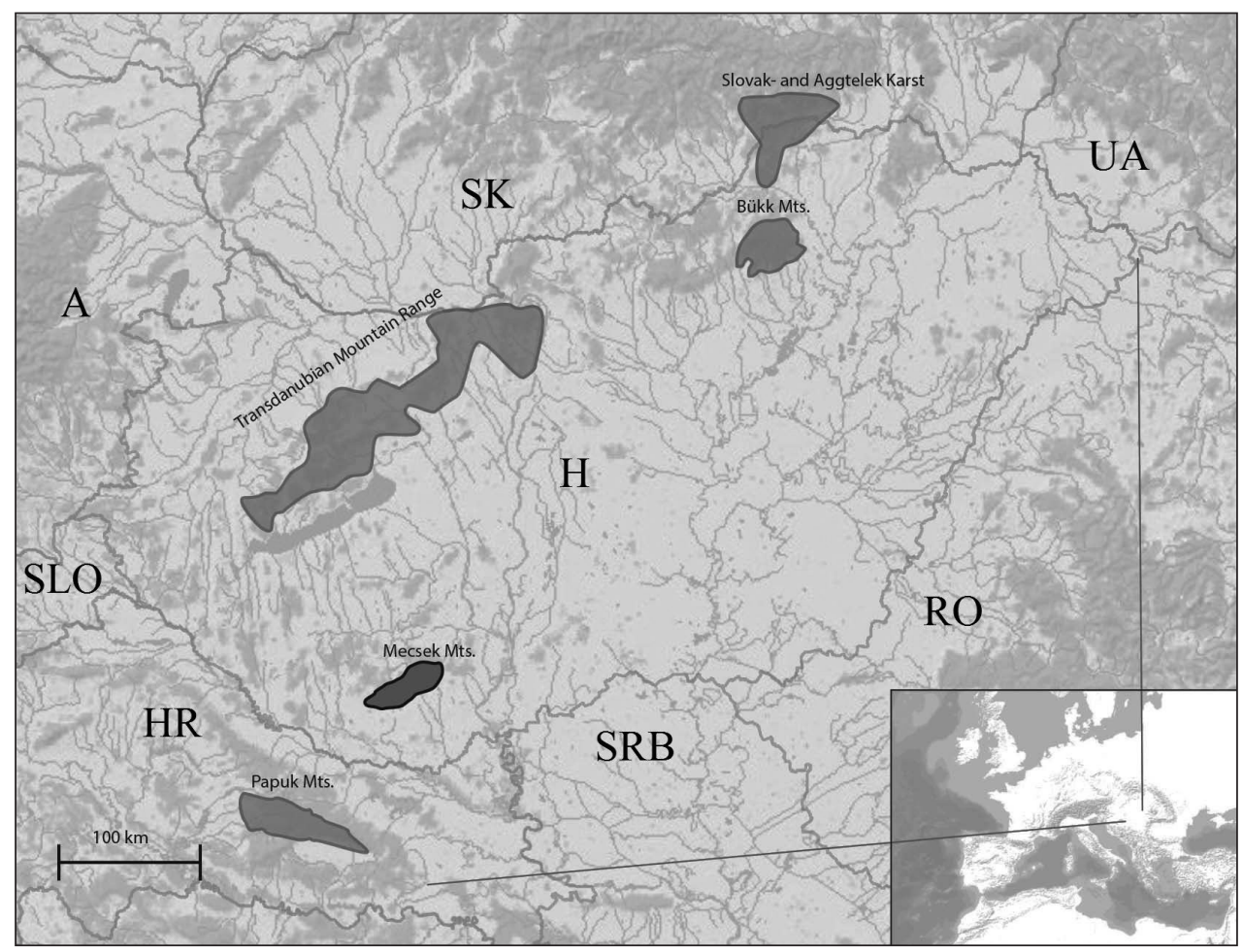

Figure I. Location of the Mecsek Mts. and the nearby isolated mountain ranges within Europe.

antennae and the mouth parts, and two drawings about the second gnathopod's propodus and the telson. Later the author gave additional data on the body length and the telson (Schellenberg 1935). Gebhardt mentioned the species'distribution from pools of the Abaligeti Cave's main passage in various papers (Gebhardt 1934, 1963, 1967). The species rank was proposed for the first time in Méhely’s synthetic work (Méhely 1941), wherein a drawing of the pleopod's retinacles and some data about the lacinia mobilis are also presented. Dudich (1941) discussed 'Niphargus foreli gebhardti' from the Abaligeti Cave as a fauna element of the historical Hungary. More recent sampling revealed new records of the species from Vadetetős Sinkhole, Szajha-felső Sinkhole, Spirál Sinkhole, Gilisztás Cave and Trió Cave (all Mecsek Mts.; see Angyal and Balázs 2013).

The holotypes of both species are either in an unknown place or had been destroyed. Although we identified the distinguishing characters of $N$. gebhardti and $N$. molnari, and presented comparative drawings of them (Angyal and Balázs 2013), the morphology of both species is unsuficiently known and cannot be used in a broader comparative research of Niphargus. In order to follow modern trends in taxonomy, we revised all possible sources of data that might increase the robustness of taxonomic conclusions (Padial et al. 2010). We provide a detailed and richly illustrated redesription of $N$. molnari and N. gebhardti with cytochrome c oxidase subunit I (COI) sequences as barcodes. We also present comparative scanning electron micrographies which 
are - to our knowledge - the first comparative micrographies of Niphargus. Moreover, we present phylogenetic relationships of both species within the genus Niphargus using three independent molecular markers and summarize field observations that may indicate species' ecology.

\section{Material and methods}

\section{Sampling sites and sampling}

Samples for the redescription were collected in the Abaligeti Cave (N46 $8^{\prime} 11.89^{\prime \prime}$, E18 $\left.6^{\prime} 59.40 "\right)$, which is located in Southern Hungary, Western Mecsek in Abaliget village, near Pécs city. The altitude of the cave entrance is $219 \mathrm{~m}$ above sea level. With its three collaterals and the main passage, the total length of the cave is $2000 \mathrm{~m}$. Its lowest point below the entrance is $10 \mathrm{~m}$, while its highest point is $38 \mathrm{~m}$. Shallow pools of water in the cave are of two types: some are formated by dripping water of the dripstones whereas others are filled during floods and contain residual water. The cave was regulary visited between 2010 and 2013 to characterize its fauna. For the morphological and molecular taxonomic analysis in total 18 and 20 specimens of $N$. molnari and $N$. gebhardti respectively were collected on 23 March 2013. Niphargus molnari was found in the stream of the Western 2. collateral and N. gebhardti was collected from a permanent pool in a lateral chamber of 'Karthago romjai' hall in the main passage and from a pool at the end of Western 2. collateral, near Akácos Sinkhole's entrance (Fig. 2). An additional specimen of $N$. gebhardti for molecular studies was collected from a pool of the Szajha-felső Sinkhole ( $46^{\circ} 8^{\prime} 5.4^{\prime \prime N}, 18^{\circ} 7^{\prime} 8.22$ E) $30 \mathrm{~m}$ vertical distance and $100 \mathrm{~m}$ horizontal distance from the entrance. The cave is situated in the area of a platform right above the Abaligeti Cave, $283 \mathrm{~m}$ above sea level. The two caves are supposedly connected, their entrances are approximately $1 \mathrm{~km}$ from each other (Dezsö 2011). Specimens were collected using entomological (soft) forceps and were fixed and stored in $96 \%$ ethanol.

\section{Morphological studies}

Cleared and stained exoskeletons of 10 (N. molnari) and 11 (N. gebhardti) specimens were dissected under a Leica MZ75 and a Leica M125 stereomicroscope. Slides were examined using a Leica DM 1000 light microscope. Drawings were made using a drawing tube mounted on the light microscope. Measurements were made using the AnalySIS Program Package, the computer was connected with a Zeiss Axioscope II light microscope. In total 230 morphological characters on each speciemens were examined according to the characters of the DELTA program package (Fišer et al. 2009) which were recorded in an Excel data matrix. Scanning micrographs of two individuals of each species about the main characters were made with a HITACHI S-2600 N scan- 


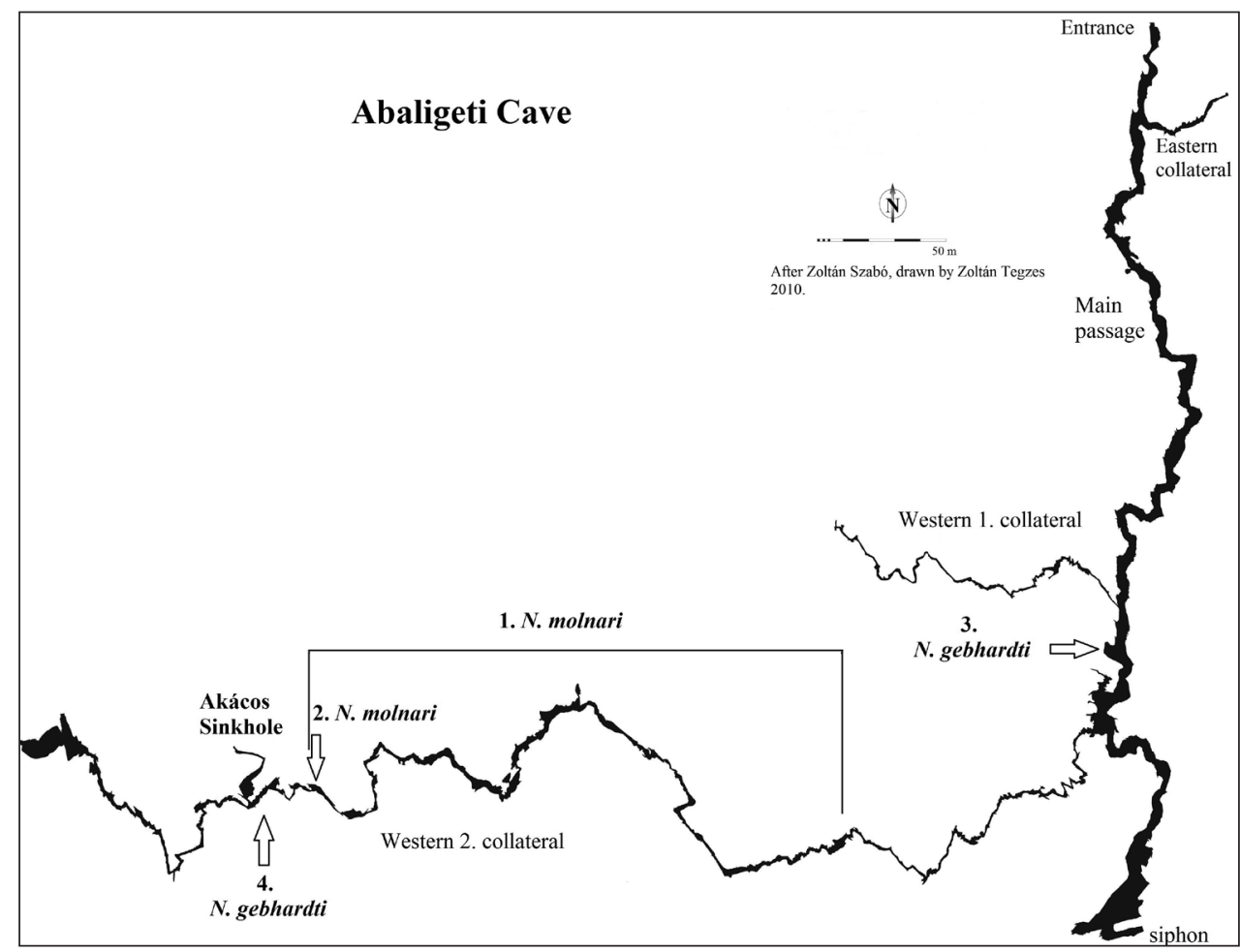

Figure 2. Distribution of the two species within the Abaligeti Cave. I N. molnari along the stream of the Western 2. collateral $2 N$. gebhardti in a permanent pool of 'Karthago romjai' $3 N$. gebhardti in a permanent pool near the Akácos Sinkhole's entrance.

ning electron microscope. Specimens were placed in absolute alcohol for one day, then cleaned in an EMAG Emmi-16 Ultrasonic Cleaner and dried out on air. Dry samples were sticked onto holders and were sputter-coated by gold-palladium. Micrographs were digitally edited.

\section{Molecular studies}

DNA extraction was performed using QIAamp DNA Microcit ${ }^{\bullet}$ (Qiagen) or Sigma Aldrich GenElute Mammalian Genomic DNA Miniprep Kit ${ }^{\circ}$ following the manufacturer's instructions. Only a few pereopods were used for DNA isolation of each animal. The following primer pairs were used for PCR amplifications of COI, 28S rDNA fragment and histone (H3). For COI: LCO 1490 - HCO 2198 (Folmer et al. 1994), for 28S rDNA: $28 \mathrm{~S}$ lev2 - 28S des2 or $28 \mathrm{~S}$ rtest2 (Verovnik et al. 2005, Zakšek et al. 2007) and H3aF2-H3aR2 (Colgan et al. 2000) for histone (H3). Details on PCR conditions are listed in Suppl. material 1. PCR products were cleaned using Roche High Pure Purification Kit ${ }^{\circledR}$ or Exonuclease I and Alkaline Phosphatase (Fermentas, 
Germany) according to manufacturer's instruction. The fragments were sequenced in both directions using PCR amplification primers using ABI 3130 sequencer in the Laboratory of Molecular Taxonomy in Budapest or Macrogen Europe (Amsterdam, The Netherlands). Contigs were assembled and sequences were edited using Geneious Pro 5.5.6. (Biomatters, New Zeland).

\section{Phylogenetic analysis}

In order to recover phylogenetic relationships of $N$. molnari and N. gebhardti within the genus Niphargus, a dataset of three molecular markers were complied, using available Niphargus sequences from previous studies (see Suppl. material 2 for references) and Synurella ambulans as outgroup taxon (Švara et al. submitted, Meleg et al. 2013). Altogether 104 taxa were included in the final dataset. List of taxa and sequences with GenBank accession numbers used in the analyses are listed in Suppl. material 2. The sequences were aligned using MAFFT 7 (Katoh and Standley 2013). Each sequence alignment was concatenated to the joint dataset and analysed as a single dataset in phylogenetic analysis. The length of combined dataset, including sequences of COI, 28S rDNA and H3 was $2068 \mathrm{bp}$. A general time-reversible model with a proportion of invariant sites and a gamma distribution of rate heterogeneity $(\mathrm{GTR}+\mathrm{I}+\mathrm{\Gamma})$ assuming six discrete gamma categories was chosen as the most appropriate model according to AIC and BIC criteria, using ModelGenerator (Keane et al. 2006). Phylogenetic relationships were reconstructed with Bayesian inference (BA) using MrBayes v3.2 (Ronquist and Huelsenbeck 2003). Two parallel searches with four chains each were run for 20 million generations, sampled every $1000^{\text {th }}$ generation. After discarding the first $25 \%$ of the sampled trees, the final tree was constructed according to the $50 \%$ majority rule. MrBayes phylogenetic analysis was run on the CIPRES Science Gateway, www.phylo.org (Miller et al. 2012).

\section{Results}

Redescription of Niphargus molnari Méhely, 1927

Order Amphipoda Latreille, 1816

Suborder Gammaridea Latreille, 1802

Family Niphargidae G. Karaman, 1962

Genus Niphargus Schiödte, 1849

\section{Niphargus molnari Méhely, 1927}

Niphargus molnari sp. n.: Méhely 1927 type locality: Mánfai-kőlyuk Cave; Data from the original description is available in Suppl. material 3. 
N. leopoliensis molnari: Schellenberg 1933, samples from the Abaligeti Cave, morphological data.

N. molnari: Schellenberg 1935, morphological data.

N. leopoliensis molnari, N. molnari: Gebhardt 1933, 1934, 1963, 1967 distributional data N. molnari: Méhely 1941 additional morphological data.

N. molnari: Angyal and Balázs 2013 morphological and distributional data.

Material examined for redescription. 7 females and 3 males from the stream of the Western 2. collateral of the Abaligeti Cave (Cadastre number: 4120-1, Hungarian Cave Cadastre), collected in 23 March 2013 (leg. D. Angyal and A. Illés), dissected and mounted on slides; additional 4 specimens not dissected. Slides were deposited in the Collection of Crustaceans of the Hungarian Natural History Museum with the following codes: N.MOL-02, N.MOL-03, N.MOL-04, N.MOL-06, N.MOL-07, N.MOL-08, N.MOL-09, N.MOL-10, N.MOL-11, N.MOL-12. Diagnostic voucher number of specimen used for molecular studies: NB555 (N. molnari, coll. data: Abaligeti Cave, Western 2. collateral, stream, 23 March 2013, leg. D. Angyal \& A. Illés).

COI Gen Bank Accession Number: KP967552

Diagnosis. Small to medium-sized niphargid; epimeral plate III postero-ventral corner sharply inclined. Telson with 3-4 apical spines, 1-3 lateral spines, 0-2 lateral plumose setae, 0-2 spines in cleft, dorsal surface with 1-3 spines in mediobasal position. Maxilla I outer lobe with 7 spines, 1.-3. pluri-toothed, 4.-7. variable (uni-, bi-, pluri-toothed). Gnathopod I and gnathopod II dactyli with single seta on outer margin. Gills II-VI ovoid, approximately same size as pereopod VI coxa, posterior margin slightly concave. Pleopods I-III with 2 retinacles on each. Uropod I lenght of endopodite: length of exopodite ratio as 1.00: (1.00-1.20) on males and 1.00: (1.15-1.18) on females. Uropod III sexually dimorphic, exopodite rod-shaped, distal article of exopodite on males $83-115 \%$ of proximal article length and $18-73 \%$ on females.

Description. Body and telson. Small to medium-sized species, females are 6.4 $\mathrm{mm}$ to $9.0 \mathrm{~mm}$, males are $7.8 \mathrm{~mm}$ to $10.6 \mathrm{~mm}$. Head length up to $13 \%$ of body length; rostrum absent. Pereonites I-VI without setae; pereonite V, VI, VII with 1 postero-ventral seta each. Pleonites I-III with 3-6 setae along dorso-posterior margin (Fig. 3). Epimeral plate II ventral and posterior margins straight or sinusoid, ventropostero-distal corner approximately perpendicular and pointed; along ventral margin 1-3 spiniform setae; along posterior margin 4-6 thin setae (Figs 3, 4). Epimeral plate III ventral margin convex and posterior margin straight, ventropostero-distal corner sharply inclined, strongly produced; along ventral margin 2-3 spiniform setae; along posterior margin 4-6 thin setae (Figs 3, 4). Urosomite I postero-dorso-laterally with 1-2 spiniform seta; urosomite II postero-dorso-laterally with 2-3 spiniform setae; urosomite III without setae. Near insertion of uropod I 1 spiniform seta (Fig. 3).

Telson length: width as 1.0: 0.6-0.8; cleft 71-87\% of length; lobes apically rounded. Telson spines (per lobe): 3-4 apical spines; lateral margins with 1-3 spine, 0-2 plumose setae; $0-2$ in cleft spines, dorsal surface with 1-3 basal spines in mediobasal position (Figs 4, 9). Length of apical spines 20-25\% of telson length. 


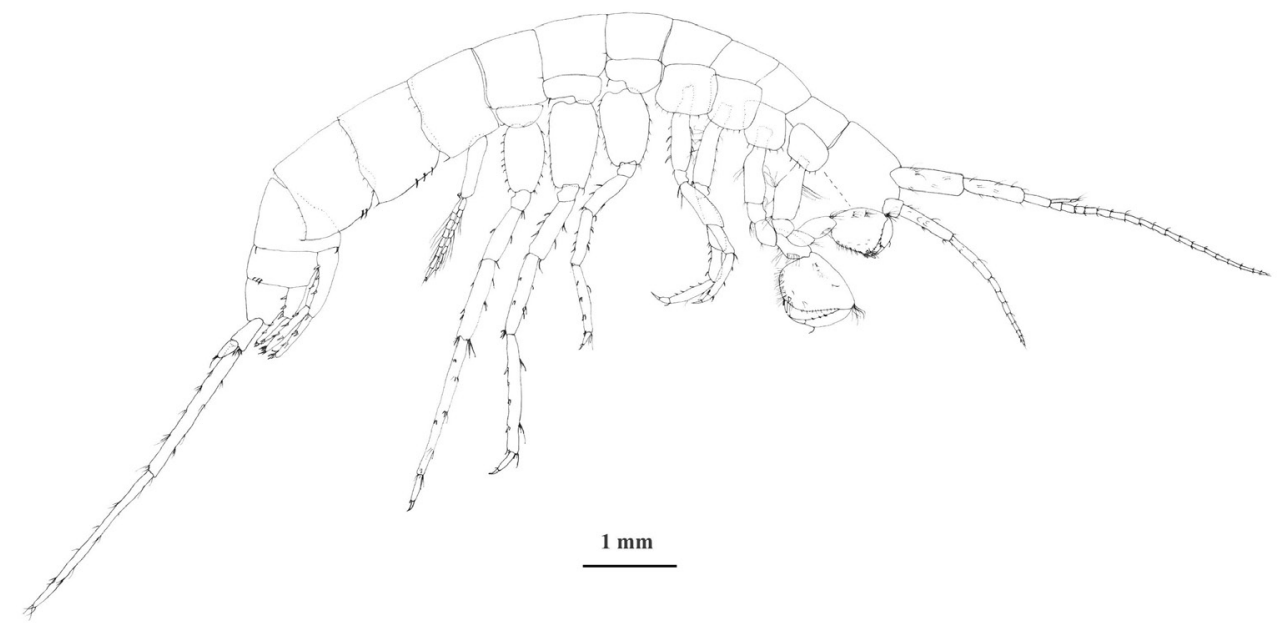

Figure 3. $N$. molnari, male from the Abaligeti Cave, lateral view. Telson, mouthparts and pleopods II-III are not drawn.

Antennae and mouthparts. Antenna I 35-48\% of body length. Flagellum with up to 19 articles; each article with 1 long aesthetasc. Peduncle article 1:2: 3 proportions 1.0: 0,78 (0.72-0.88): 0,4 (0.36-0.46). Proximal article of peduncle dorso-distally slightly produced. Accessory flagellum biarticulated; distal article shorter than one-half of the proximal article. Lengths of antennae I: II as 1.0: 0.50. Flagellum of antenna II with 6-8 articles. Lengths of peduncle articles $4: 5$ as 1.0: (0.84-0.95); flagellum $54-70 \%$ of peduncle length (articles $4+5$ ) (Fig. 5).

Inner lobes of labium longer than half of outer lobes (Fig. 5).

Left mandible: incisor with 5 teeth, lacinia mobilis with 4 teeth; between lacinia and molar 6-9 thick, serrated setae, long seta at base of molar absent (Fig. 5).

Right mandible: incisor processus with $4-5$ teeth, lacinia mobilis with several small denticles (more then 12), between lacinia and molar 6-7 thick, serrated setae, long seta at base of molar present. Proportions of mandibular palp articles 2: 3 (distal) as 1.0: 1,20 (1.17-1.32). Proximal palp article without setae; second article with 9-11 seta in 5-6 groups; distal article with 1 group of 3-5 'A setae'; 3 groups of 'B setae'; 16-24 'D setae'; 3-5 'E setae' (Fig. 5).

Maxilla I distal palp article with 2-3 apical and subapical setae. Outer lobe of maxilla I with 7 spines, 1-3 spines are always pluri-toothed with 3-6 lateral tooth while 4-6 spines are uni-, or bitoothed. Inner lobe with 1-2 setae (Fig. 5).

Maxilla II inner lobe slightly smaller than outer lobe; both of them setose apically and subapically, number of setae is approximately 13-23 per lobe (Fig. 5).

Maxilliped palp article 2 with 11-17 rows of setae along inner margin; distal article with dorsal seta and group of small setae at base of nail. Maxilliped outer lobe with 6-12 flattened, thick setae and 3-8 serrated setae; inner lobe with 2-3 flattened, thick setae apically and 5-9 serrated setae (Fig. 5). 


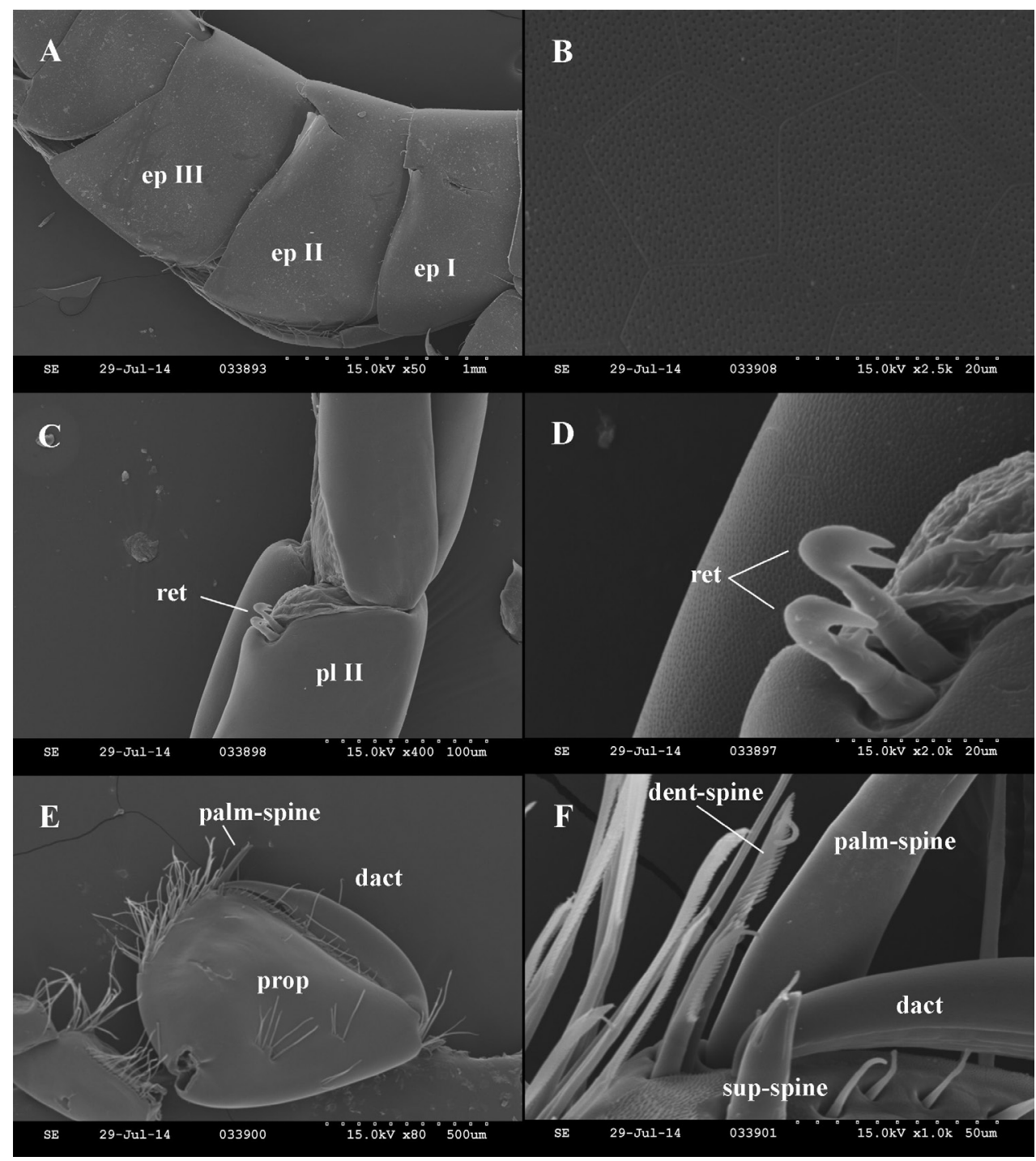

Figure 4. N. molnari, scanning electron micrographs. A epimeral plates (Ep1-3 = epimeral plates 1-3) B honeybee-cell pattern on the exosceleton (tipical feature of amphipods) $\mathbf{C}$ pleopod with two retinacles $(\mathrm{pl}-\mathrm{r}=$ pleopod ramus, ret $=$ retinaculum) $\mathbf{D}$ retinaculi on the pleopod (ret = retinaculum) $\mathbf{E}$ gnathopod II propodus (prop = propodus, sup-spine $=$ supporting spine, dact $=$ dactylus) $\mathbf{F}$ palmar region of gnathopod II propodus (dent-spine $=$ denticulated spine, sup-spine $=$ supporting spine, $\mathrm{n}=$ nail, palm-spine = palmar spine).

Coxal plates. Coxal plate I width: depth as 1.00: 1.03 (0.89-1.16), of flattened rhomboid shape, antero-ventral corner subrounded; anterior and ventral margin of coxa I with 3-6 setae (Fig. 6). Coxal plate II width: depth as 1.00: 0.84 (0.76-0.95); anterior and ventral margin with 5-8 setae. Coxal plate III width: depth as 1.00: 0.82 (0.71-1.00); along antero-ventral margin 4-7 setae (Fig. 7). Coxal plate IV width: 


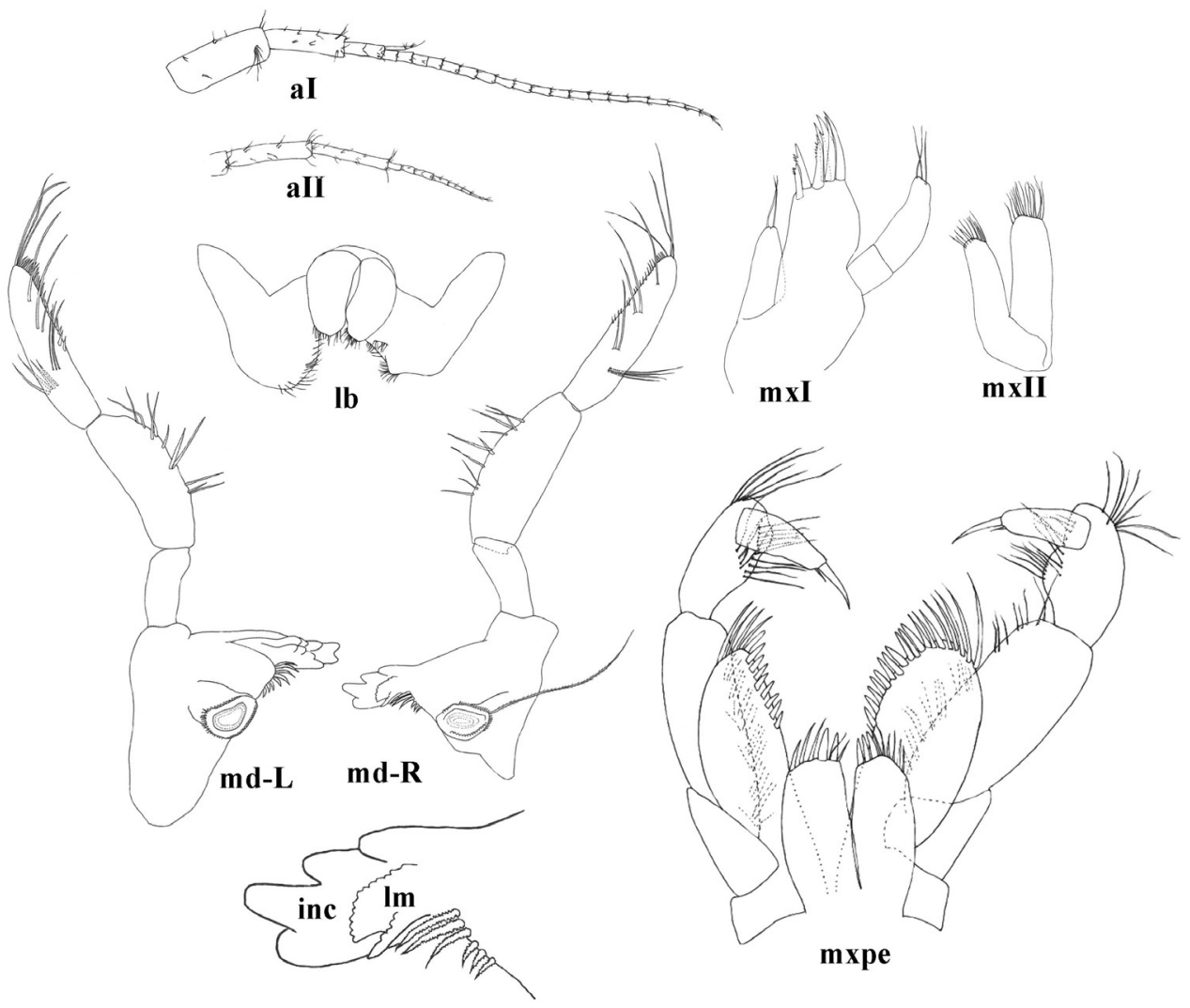

Figure 5. $N$. molnari, $\mathrm{aI}=$ antenna $\mathrm{I}, \mathrm{aII}=$ antenna II, $\mathrm{mxI}=$ maxillaI, $\mathrm{mxII}=$ maxilla $\mathrm{II}, \mathrm{md}-\mathrm{R}=$ right mandibula, $\mathrm{lm}=$ lacinia mobilis, inc $=$ incisor, $\mathrm{md}-\mathrm{L}=$ left mandibula, $\mathrm{lb}=$ labium, mxpe: maxilliped.

depth as 1.00: 1.03 (1.26-0.88); posteriorly concave; along antero-ventral margin 5-7 setae (Fig. 7). Coxal plates V-VI: anterior lobe well developed; along posterior margin 1 seta (Fig. 7). Coxal plate VII half-egg shaped, along posterior margin 1 seta (Fig. 7). Gills II-VI ovoid, with approximately same size as coxa VI (Fig. 7).

Gnathopods. Basis width is 38 (33-45)\% of basis length. Gnathopod I ischium with 4-8 posterodistal setae in 1 row. Carpus length $62(57-75) \%$ of basis length and $87(80-100) \%$ of propodus length. Anterior margin of carpus only with distal group of setae; carpus posteriorly with transverse rows of setae proximally and a row of lateral setae, posterior enlargment small. Propodus subquadrate, palm convex. Along posterior margin 6-8 rows of denticulated setae. Anterior margin with 10-17 setae in 2-3 groups, antero-distal group with 6-12 setae. Group of 2-4 facial setae below (proximal of) palmar spine; 2-4 single surface setae present. Palmar corner with palmar spine, single supporting spine on inner surface, and 3 (rarely 4) denticulated, thick spiniform setae on outer side. Nail length 36 (34-37)\% of total dactylus length; along anterior margin single seta; along inner margin 4-5 setae (Fig. 6). 

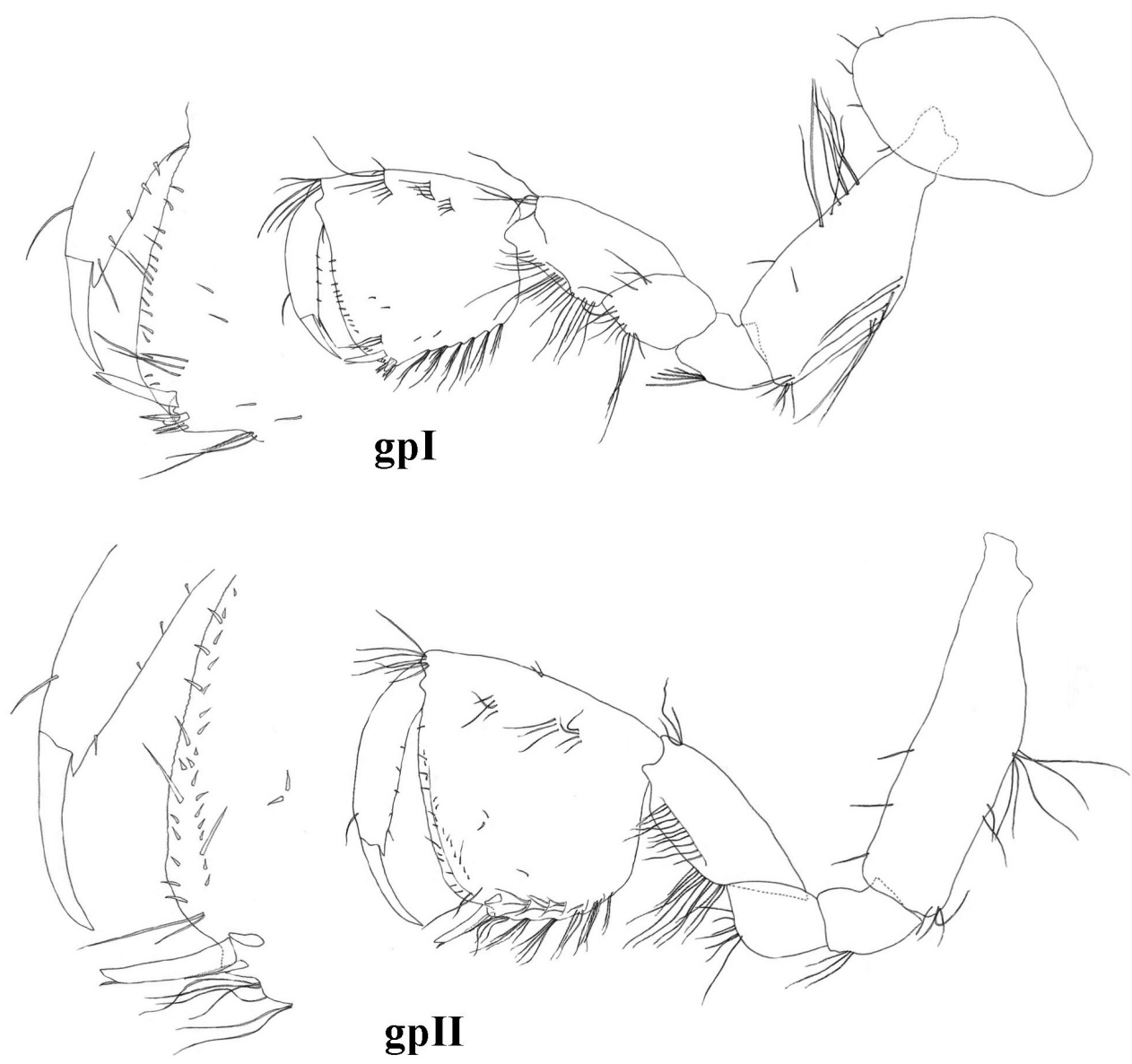

\section{gpII}

Figure 6. $N$. molnari, gpI = gnathopod I, gpII = gnathopod II.

Gnathopod II basis width: length as 1.0: 0.26 (0.21-0.29). Ischium with 2-6 postero-distal setae. Carpus length 56 (50-61)\% of basis length and 86 (71-94)\% of propodus lenght. Anterior margin of carpus only with distal row of setae; carpus posteriorly with transverse rows of setae proximally, a row of lateral setae; posteroproximal bulge small, positioned proximally. Propodus medium-sized (sum of length, diagonal and palm length measures up to 19 (15-21)\% of body length) and larger than propodus of gnathopod I (1.0: 0.57 (0.65-0.85)). Propodus rectangular, palm convex. Posterior margin convex with 6-9 rows of denticulated setae. Anterior margin with 10-20 setae in 3-5 groups; antero-distal group with 7-9 setae. 1 group of 2-3 facial setae below (distal of) palmar spine; 1-4 individual surface setae present. Palmar corner with strong palmar spine, single supporting spine on inner surface, and 1 denticulated, thick spiniform seta on outer side. Nail length $31(22-36) \%$ of total dactylus length. Along anterior margin single seta; along inner margin 4-6 short setae (Figs 4, 6). 


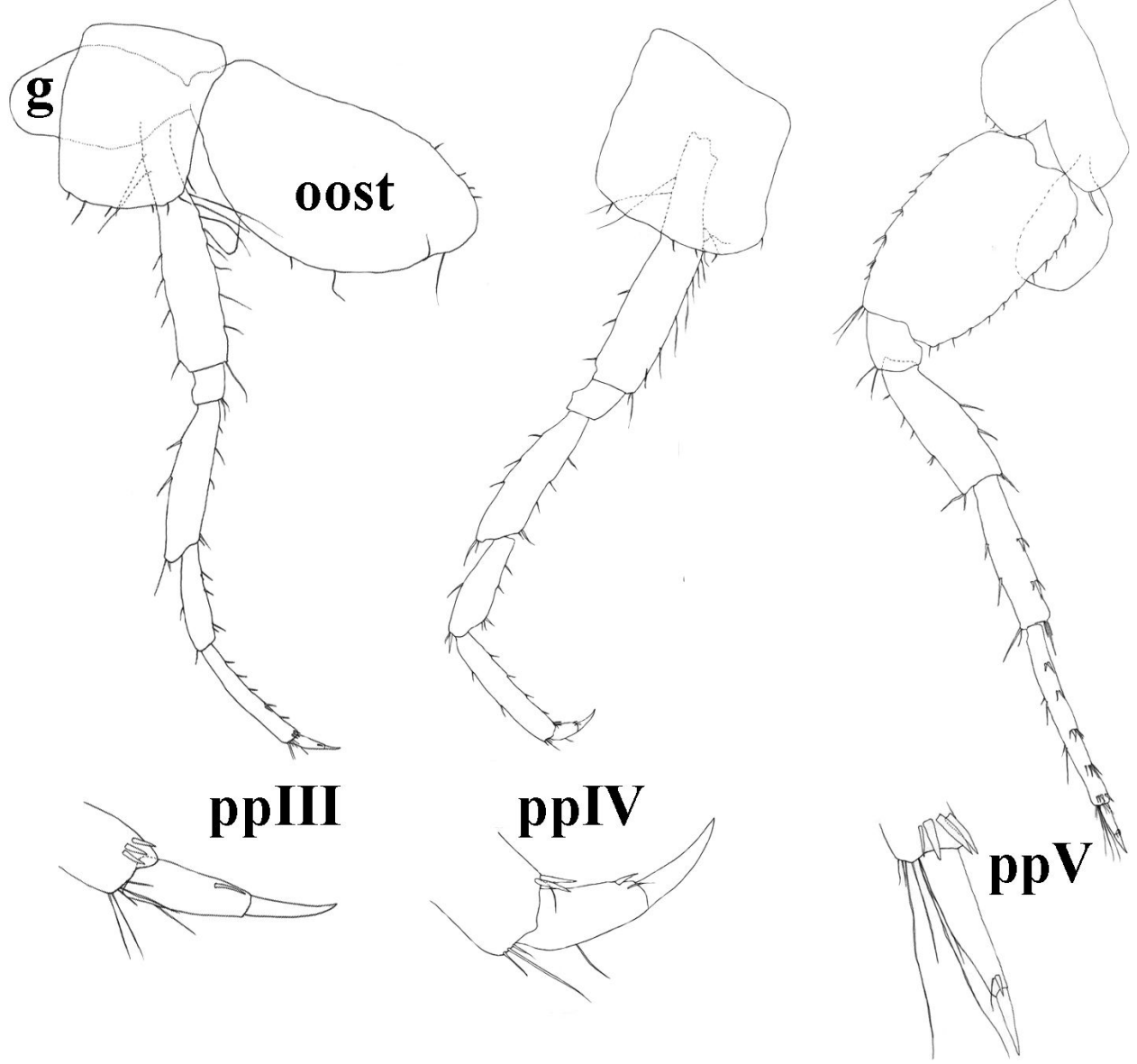

Figure 7. $N$. molnari, $\mathrm{ppIII}=$ pereopod III, $\mathrm{ppIV}=$ pereopod $\mathrm{IV}, \mathrm{ppV}=$ pereopod $\mathrm{V}, \mathrm{g}=$ gill, oost $=$ oostegit.

Pereopods III-IV. Proportions of pereopods III: IV as 1: 0.95 (0.93-0.97). Dactylus IV 45 (39-51)\% of propodus IV; nail length 47 (39-52)\% of total dactylus length. Dactyli III-IV with one dorsal plumose seta, one spine-like seta at the base of the nail, and tiny seta near the spine-like seta (sometimes not visible or absent). Additional spiniform setae on posterior margin are absent (Fig. 7).

Pereopods V-VII. Proportions of pereopods V: VI: VII as 1.00: 1.4 (1.37-1.54): 1.5 (1.42-1.61). Pereopod VII length 47 (42-52)\% of body length. Basis V-VII narrow with convex posterior margins. Basis $\mathrm{V}$ width is $70(60-78) \%$ of length, basis VI is 67 (59-76)\% of length and basis VII is 66 (56-76)\% of length. Basis V with small posterodistal lobe, posterior margin with 8-13 setae, anterior margin with 6-8 groups of setae. Dactylus V with one dorsal plumose seta, one spine-like seta at the base of the nail, and tiny seta near the spine-like seta (sometimes not visible or 


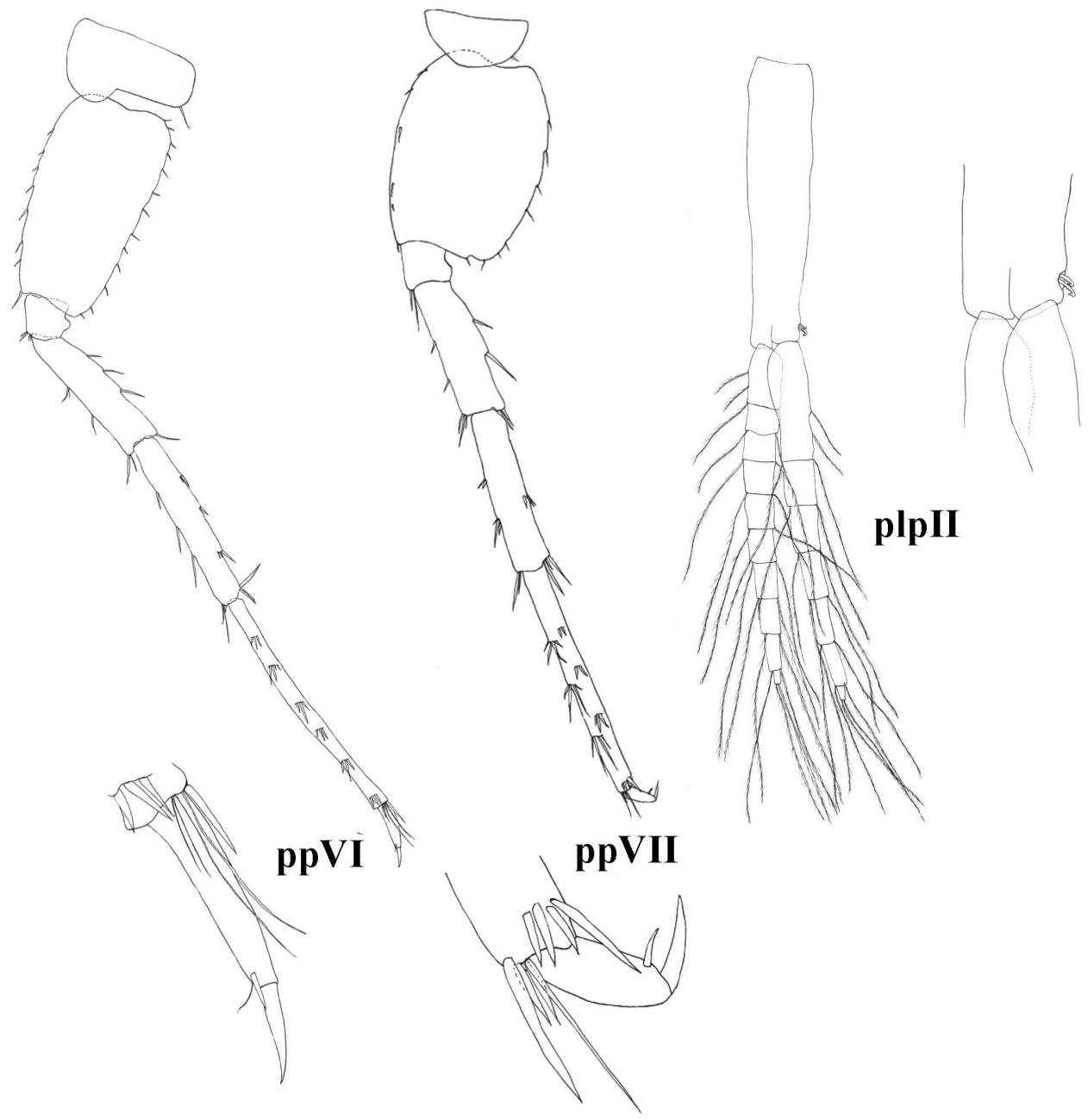

Figure 8. $N$. molnari, ppVI = pereopod VI, ppVII = pereopod VII, plpII = pleopod II

absent). Additional spiniform setae on posterior margin are absent (Fig. 7). Basis VI with small posteriodistal lobe, posterior margin with 9-14 setae, anterior margin with 6-10 setae. Dactylus VI with one dorsal plumose seta (sometimes not visible or absent), one spine-like seta at the base of the nail, and tiny seta near the spinelike seta (sometimes not visible or absent). Additional spiniform setae on posterior margin are absent (Fig. 8).

Basis VII posterior margin with 6-13 setae, anterior margin with 6-11 groups of setae. Total number of basis setae is 15-21. Dactylus VII length 26 (24-29)\% of propodus VII length; nail length 26 (16-33)\% of total dactylus length. Dactylus VII with one spine-like seta at the base of the nail. Additional spiniform setae on posterior margin are absent (Fig. 8). 


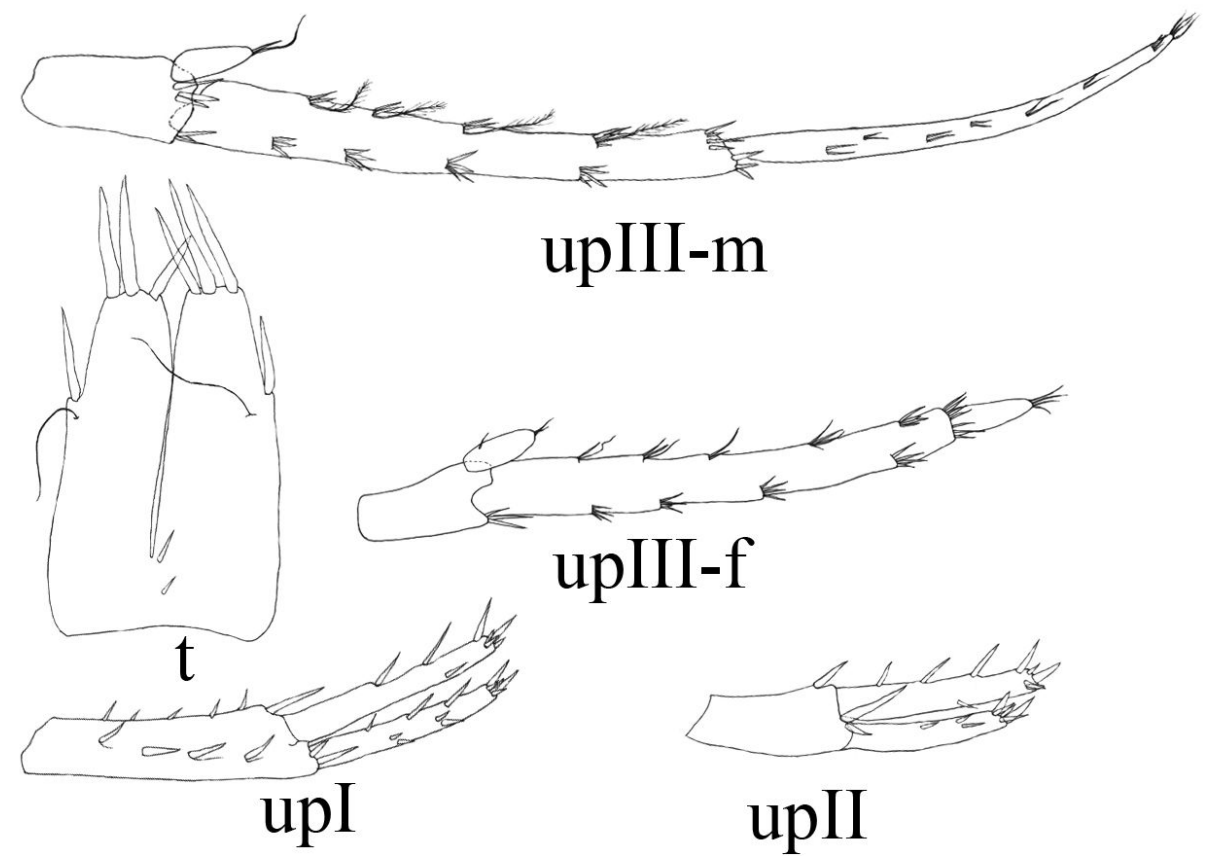

Figure 9. $N$. molnari, $\mathrm{t}=$ telson, upI $=$ uropod I, upII = uropod II, upIII-f $=$ female's uropod III, upIII-m = male's uropod III.

Pleopods. Pleopods I-III with 2-hooked retinacles. Pleopod II rami of 16-20 articles each (Figs 4, 8).

Uropods. Uropod I basipodite with 6 dorso-lateral and 6 dorsomedial spinifom setae. Length ratio endopodite: exopodite as 1.00: 0.89 (0.83-1.0); rami slightly curved. Endopodite total setae number $2-4$ in $2-3$ groups, apically 5 spinifom setae. Exopodite with 2-7 spines; apically 5 spinifom setae (Fig. 9).

Uropod II endopodite: exopodite length as 1.00: 0.81 (0.77-0.9) (Fig. 9).

Uropod III up to $38-46 \%$ (males) and $12-42 \%$ (females) of body length. Basipodite with no lateral seta and 3-6 apical spiniform and thin setae. Endopodite 58-61\% (males) and 48-70\% (females) of basipodite length, endopodite apically with 1-2 thin-flexible and spiniform setae; laterally $0-1$ seta. Exopodite of uropod III rod-shaped, distal article of exopodite $83-115 \%$ (males) and 18-73\% (females) of proximal exopodite article length. Proximal article with 4-5 groups of plumose, thin-flexible and spiniform setae along inner margin and 4 groups of thin-flexible and spiniform setae along outer margin. Distal article with 3-6 apical setae; lateral setae only in males (Fig. 9). 


\section{Redescription of Niphargus gebhardti Schellenberg, 1934 \\ Order Amphipoda Latreille, 1816 \\ Suborder Gammaridea Latreille, 1802 \\ Family Niphargidae G. Karaman, 1962 \\ Genus Niphargus Schiödte, 1849}

\section{Niphargus gebhardti Schellenberg, 1934}

Niphargus foreli gebhardti n. subsp.: Schellenberg 1934; Type locality: Abaligeti Cave.

Data from the original description is available in Suppl. material 3.

$N$. foreli gebhardti: Schellenberg 1935, additional morphological data

N. foreli gebhardti, N. gebhardti: Gebhardt 1934, 1963, 1967, distributional data

N. gebhardti: Méhely 1941, morphological data

$N$. foreli gebhardti: Dudich 1941, distributional data

N. gebhardti: Angyal and Balázs 2013, morphological and distributional data

Material examined for redescription. 7 females and 4 males from a permanent pool in the main passage near 'Karthago romjai' hall of the Abaligeti Cave (Cadastre number: 4120-1, Hungarian Cave Cadastre), collected on 23 March 2013 (leg. D. Angyal \& A. Illés), dissected and mounted on slides; additional 4 specimens not dissected. Slides were deposited in the Collection of Crustaceans of the Hungarian Natural History Museum with the following codes: N.GEB-02, N.GEB-03, N.GEB-04, N.GEB-05, N.GEB-08, N.GEB-10, N.GEB-14, N.GEB-15, N.GEB-17, N:GEB-18, N.GEB-20. Diagnostic voucher numbers of specimens used for molecular studies: NB 550 (N. gebgardti, coll. data: Abaligeti Cave, main passage, pool, 23 March 2013, leg. D. Angyal \& A. Illés), NB 551 (N. gebgardti, coll. data: Szajha-felső Sinkhole (Cadastre number: 4120-16), small pool, 2 April 2013, leg. D. Angyal \& Z. Tegzes).

COI Gen Bank Accession Numbers: KP967553 (Abaligeti Cave), KP967554 (Szajha-felső Sinkhole)

Diagnosis. Small-sized niphargid; epimeral plate III postero-ventral corner subrounded. Telson with 3-6 apical spines, $0-2$ lateral spines, $0-1$ lateral plumose setae, $0-1$ spines in cleft and $0-1$ dorsal surface spines. Maxilla I outer lobe with 7 spines, pluri-, uni-, bi-toothed spines alternating. Gnathopod I and gnathopod II dactyli with single seta on outer margin. Gills II-VI ovoid. Pleopods I-III with 3, rarely 4 retinacles on each. Uropod I lenght of endopodite: length of exopodite ratio as 1.00: (1.09-1.11) on males and 1.00: (1.03-1.17) on females. Uropod II sexually dimorphic, exopodite rod-shaped, distal article of exopodite on males $95-155 \%$ of proximal article length and $52-72 \%$ on females.

Description. Body and telson. Small-sized niphargid species, females $4.9-5.9 \mathrm{~mm}$, males 5.9-7.0 mm. Head length up to 9\% of body length; rostrum absent. Pereonites 


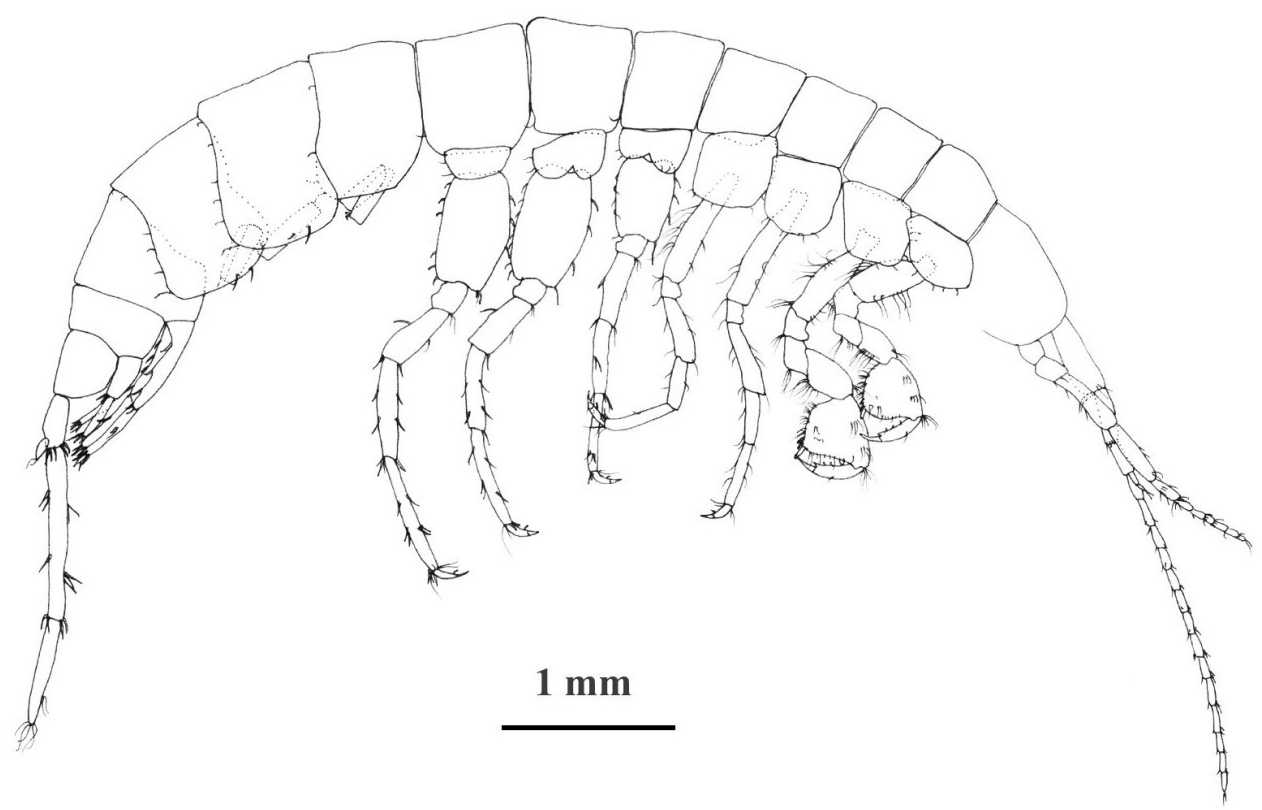

Figure 10. N. gebhardti, female from the Abaligeti Cave, lateral view. Mouthparts, rami of pleopods and telson are not drawn.

I-VI without setae; pereonite V, VI, VII with 1 postero-ventral seta each. Pleonites I-III with 1-2 setae along dorso-posterior margin. Epimeral plate II posterior and ventral margins convex, ventro-postero-distal corner rounded. Along ventral margin 1-3 spiniform setae; along posterior margin 3-4 thin setae. Epimeral plate III ventral and posterior margins convex, ventro-postero-distal corner rounded; along ventral margin 2-3 spiniform setae; along posterior margin 4 thin setae. Urosomite I posterodorso-laterally with 1 seta; urosomite II postero-dorso-laterally with 1 spiniform seta; urosomite III without setae. Near insertion of uropod I 1 spiniform seta (Figs 10, 11).

Telson length: width as 1.0: 0.88 ; cleft 74 (70-79)\% of length; lobes apically widely rounded. Telson spines (per lobe): 2-4 apical spines, 33.5 (28-39)\% of telson length; lateral margins with $0-2$ spine and $0-1$ plumose setae; $0-1$ in cleft spines, 0 or 1 dorsal surface spines, 1 basal spine (Figs 11, 16).

Antennae and mouthparts. Antenna I 37 (34-41)\% of body length. Flagellum with up to 13-16 articles; each article with 1 long aesthetasc (Fig. 11). Peduncle article 1: $2: 3$ as 1.0: 0.69 (0.60-0.76): $0.37(0.30-0.4)$. Proximal article of peduncle dorsodistally slightly produced. Accessory flagellum biarticulated; distal article $52(38-67) \%$ of proximal article. Lengths of antennae I: II as 1.0: $0.48(0.42-0.52)$. Flagellum of antenna II with 6-8 articles. Lengths of peduncle articles 4: 5 as 1.0: 0.85 (0.81-0.91); flagellum 73 (57-81)\% of peduncle length (articles 4+5) (Fig. 12).

Inner lobes of labium longer than half of outer lobes (Fig. 12).

Left mandible: incisor with 5 teeth, lacinia mobilis with 4 teeth; between lacinia and molar 5-7 thick, serrated setae, long seta at base of molar absent (Fig. 12). 


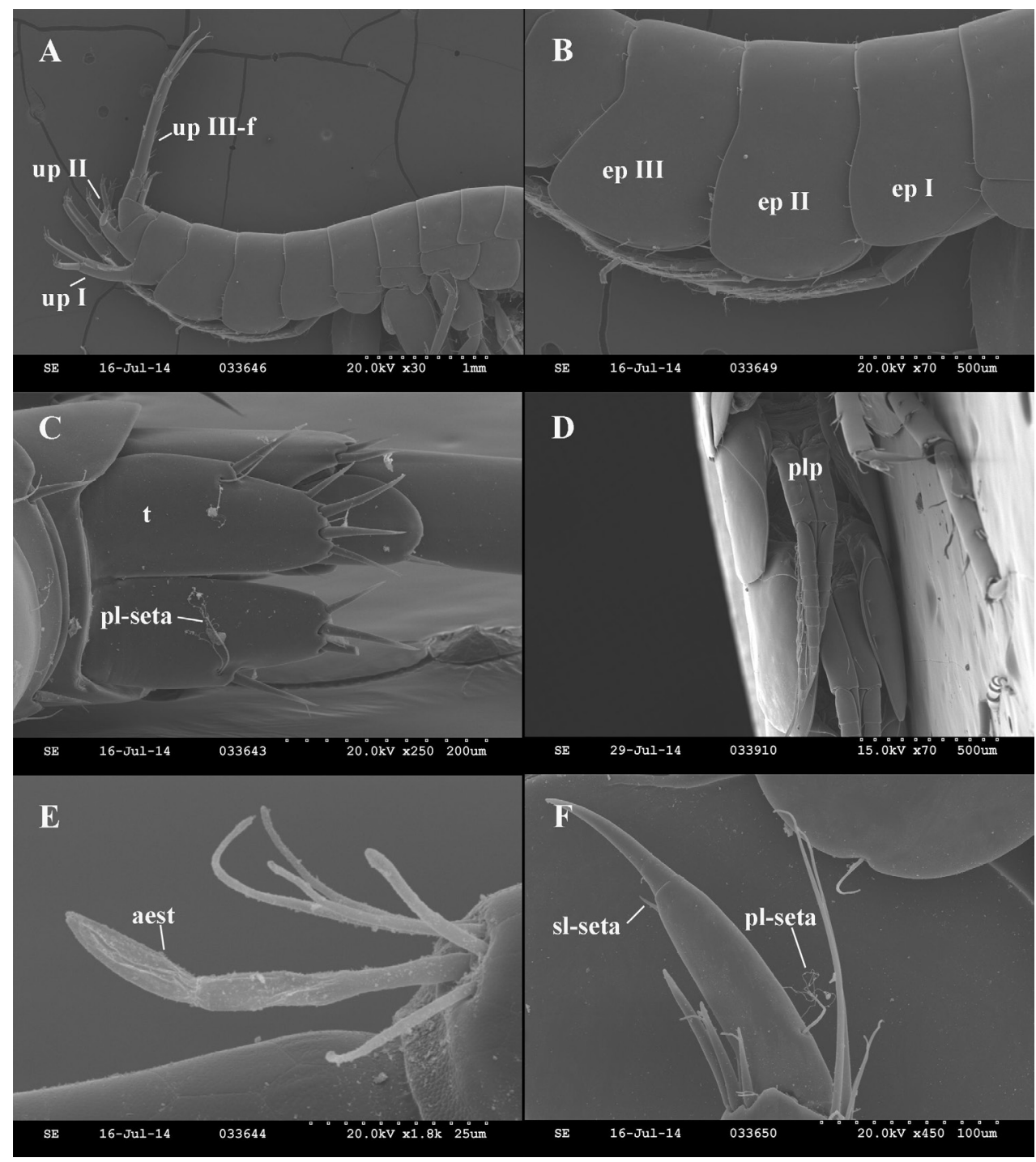

Figure II. N. gebhardti, scanning electron micrographs. A epimeral plates with uropods (Ep1-3 = epimeral plates $1-3$, upI $=$ uropod I, upII = uropod II, upIII-f = female's uropod III) B epimeral plates (Ep1-3 = epimeral plates 1-3) C telson $(\mathrm{t}=$ telson, pl-seta = plumose seta) $\mathbf{D}$ pleopods $(\mathrm{plp}=$ pleopod $)$ $\mathbf{E}$ aesthetasc on antenna I (aest $=$ aesthetasc) $\mathbf{F}$ pereopod VI dactylus (sl-seta $=$ spine-like seta at the base of the nail, pl-seta = plumose seta).

Right mandible: incisor processus with 4 teeth, lacinia mobilis with 5-6 denticles, between lacinia and molar 6-8 thick, serrated setae, 1 long seta at base of molar present. Proportions of mandibular palp articles 2: 3 (middle: distal) as 1.0: 1.1 (1.001.21). Proximal palp article without setae; second article with 4-6 seta in 3-4 groups; distal article with 1 group of 3-4 'A setae'; 2-4 of 'B setae' (single or in groups); 9-13 'D setae' and 3-5 'E setae' (Fig. 12). 

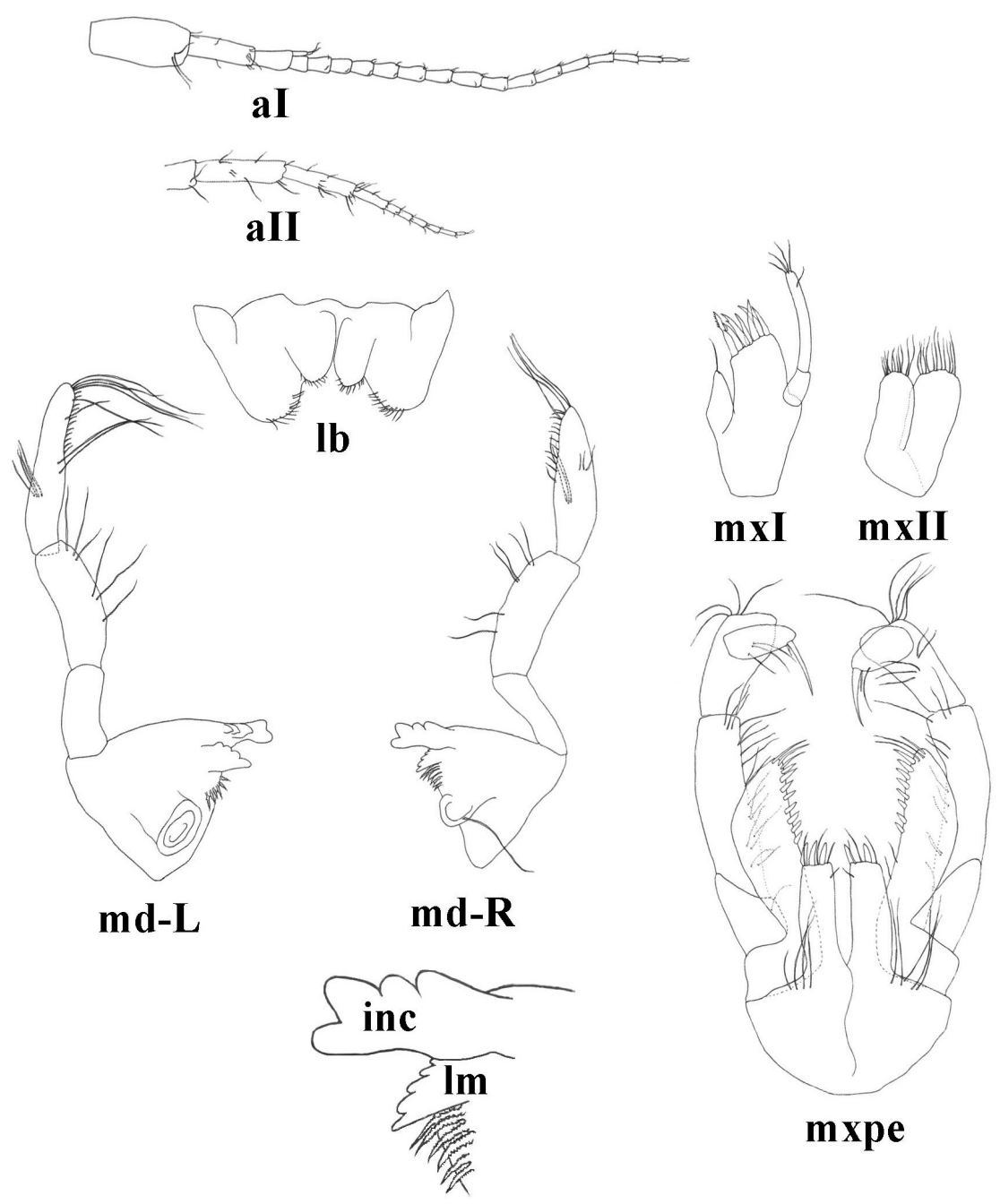

Figure 12. $N$. gebhardti, aI = antenna I, aII = antenna II, $\mathrm{mxI}=$ maxilla $\mathrm{I}, \mathrm{mxII}=$ maxilla $\mathrm{II}, \mathrm{md}-\mathrm{R}=$ right mandibula, inc = incisor, $\mathrm{lm}=$ lacinia mobilis, $\mathrm{md}-\mathrm{L}=$ left mandibula, $\mathrm{lb}=$ labium, $\mathrm{mxpe}=$ maxilliped.

Maxilla I distal palp article with 3-6 apical and subapical setae. Outer lobe of maxilla I with 7 spines, pluri-, uni-, bi-toothed spines alternating. Inner lobe with 1 seta (Fig. 12).

Maxilla II inner lobe slightly smaller than outer lobe; both of them setose apically and subapically, number of setae is approximately $6-11$ on inner lobe and 8-12 on outer lobe (Fig. 12).

Maxilliped palp article 2 with $8-11$ rows of setae along inner margin; distal article with dorsal seta and group of small setae at base of nail. Maxilliped outer lobe with 6-8 flattened, thick setae and 3-5 serrated setae; inner lobe with 2-3 flattened, thick setae apically and 2-4 serrated setae (Fig. 12). 


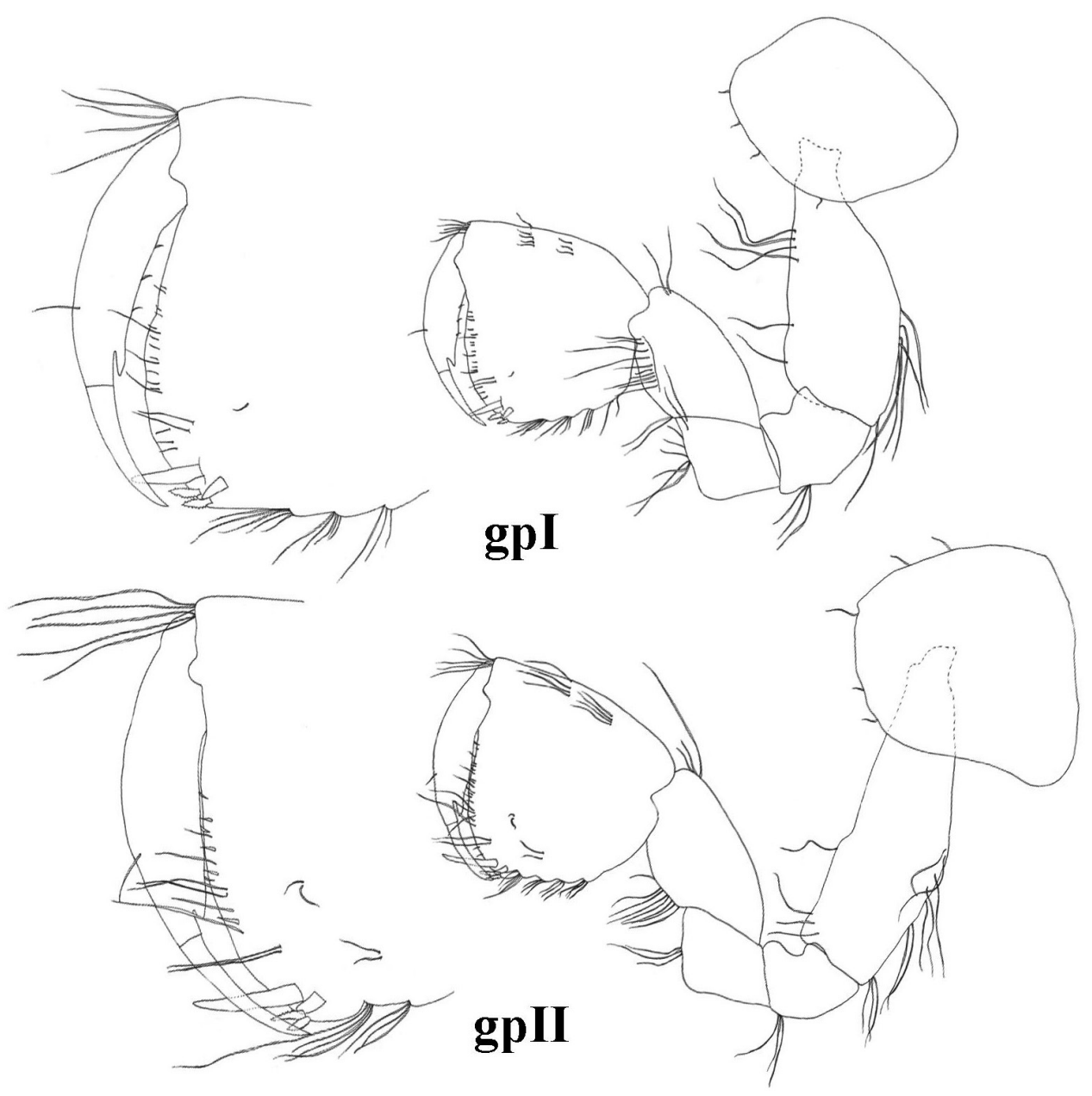

Figure 13. $N$. gebhardti, gpI = gnathopod I, gpII = gnathopod II.

Coxal plates. Coxal plate I width: depth as 1.00: $0.76(0.6-0.9)$ of flattened rhomboid shape, antero-ventral corner subrounded; anterior and ventral margin of coxa I with 4-6 setae (Fig. 13). Coxal plate II width: depth as 1.00: 0.97 (0.83-1.21); anterior and ventral margin with 3-6 setae (Fig. 13). Coxal plate III width: depth as 1.00: 1.12 (1.05-1.2); along antero-ventral margin 4-6 setae. Coxal plate IV width: depth as 1.00: 1.04 (0.97-1.12); posteriorly concave; along antero-ventral margin 4-5 setae (Fig. 14). Coxal plates V-VI with well developed anterior lobe, and smaller posterior lobe with usually 2 setae (occasionally with 1 or 3 ) in postero-ventral corner. Coxal plate VII half-egg shaped, along posterior margin 2 setae. Gills II-VI ovoid, of approximately similar size as coxa VI (Fig. 15).

Gnathopods. Gnathopod I basis width 42 (38-47)\% of basis length. Ischium with 3-4 posterodistal setae in 1 row. Carpus length $61(52-82) \%$ of basis length and 98 
(87-110)\% of propodus length. Anterior margin of carpus only with distal group of setae; carpus posteriorly with transverse rows of setae proximally and a row of lateral setae, posterior enlargment small. Propodus subquadrate, palm and posterior margin convex. Along posterior margin 3-4 rows of denticulated setae. Anterior margin with 6-11 setae in 2-3 groups, antero-distal group with 4-8 setae. Group of 2-3 facial setae below (proximal of) palmar spine; 1-4 surface setae in 1-2 groups present. Palmar corner with palmar spine, single supporting spine on inner surface, and 2-3 denticulated, thick spiniform setae on outer side. Nail length 33 (30-39)\% of total dactylus length; along anterior margin single seta; along inner margin 3-4 setae (Fig. 13).

Gnathopod II basis width: length as 1.0: $0.34(0.27-0.45)$. Ischium with 3-4 postero-distal setae in 1 row. Carpus length 59 (48-69)\% of basis length and 106 (96$111) \%$ of propodus length. Anterior margin of carpus only with distal row of setae; carpus posteriorly with transverse rows of setae, proximally a row of lateral setae; postero-proximal bulge small and positioned proximally. Propodus small to medium-sized (sum of length, diagonal and palm length measures up to $12-15 \%$ of body length) and larger than propodus of gnathopod I (1.0: 0.87 (0.78-0.96)). Propodus rectangular, palm convex. Posterior margin straight or convex with 4-5 rows of denticulated setae. Anterior margin with 3-9 setae in 1-2 groups; antero-distal group with 4-8 setae. Group of 2-4 facial setae below (proximal of) palmar spine; 2-3 surface setae in 1-2 groups present. Palmar corner with strong palmar spine, single supporting spine on inner surface, and 2-3 denticulated, thick spiniform setae on outer side. Nail length $34(29-42) \%$ of total dactylus length. Along anterior margin single seta; along inner margin 3 short setae (Fig. 13).

Pereopods III-IV. Proportions of pereopods III: IV as 1: 0.96 (0.89-1). Dactylus IV 51 (46-57)\% of propodus IV lenght; nail length 53 (44-61)\% of total dactylus length. Dactyli III-IV with dorsal plumose seta (sometimes not visible or absent), one spine-like seta at the base of the nail, and tiny seta near the spine-like seta (sometimes not visible or absent). Additional spiniform setae on posterior margin are absent (Fig. 14).

Pereopods V-VII. Proportions of pereopods V: VI: VII as 1.00: 1.3 (1.27-1.49): 1.5 (1.46-1.58). Pereopod VII length $42-45 \%$ of body length. Basis V-VII with convex posterior margins. Basis V width is $71(66-80) \%$ of length, basis VI is 68 $(64-73) \%$ of length, and basis VII is $66(63-69) \%$ of length. Basis V with small posterodistal lobe, posterior margin with 4-6 setae, anterior margin with 4-9 setae in $3+1$ groups (Fig. 14). Pereopod dactylus $V$ with one dorsal plumose seta (sometimes not visible or absent), and one spine-like seta at the base of the nail (Fig. 14). Basis VI with small posterodistal lobe, posterior margin with 6-7 setae, anterior margin with 5-8 setae in 3-4 groups. Dactylus VI with one spine-like seta at the base of the nail, and tiny seta near the spine-like seta (sometimes not visible or absent). Additional spiniform setae on posterior margin are absent (Fig. 15). Basis VII posterior margin with 5-8 setae, anterior margin with 3-5 groups of setae. Total number of basis setae is 11-15. Dactylus VII length 26 (23-35)\% of propodus VII length; nail length 28.5 $(25-38) \%$ of total dactylus length. Dactyli VI with one dorsal plumose seta (sometimes not visible or absent), one spine-like seta at the base of the nail, and tiny seta 

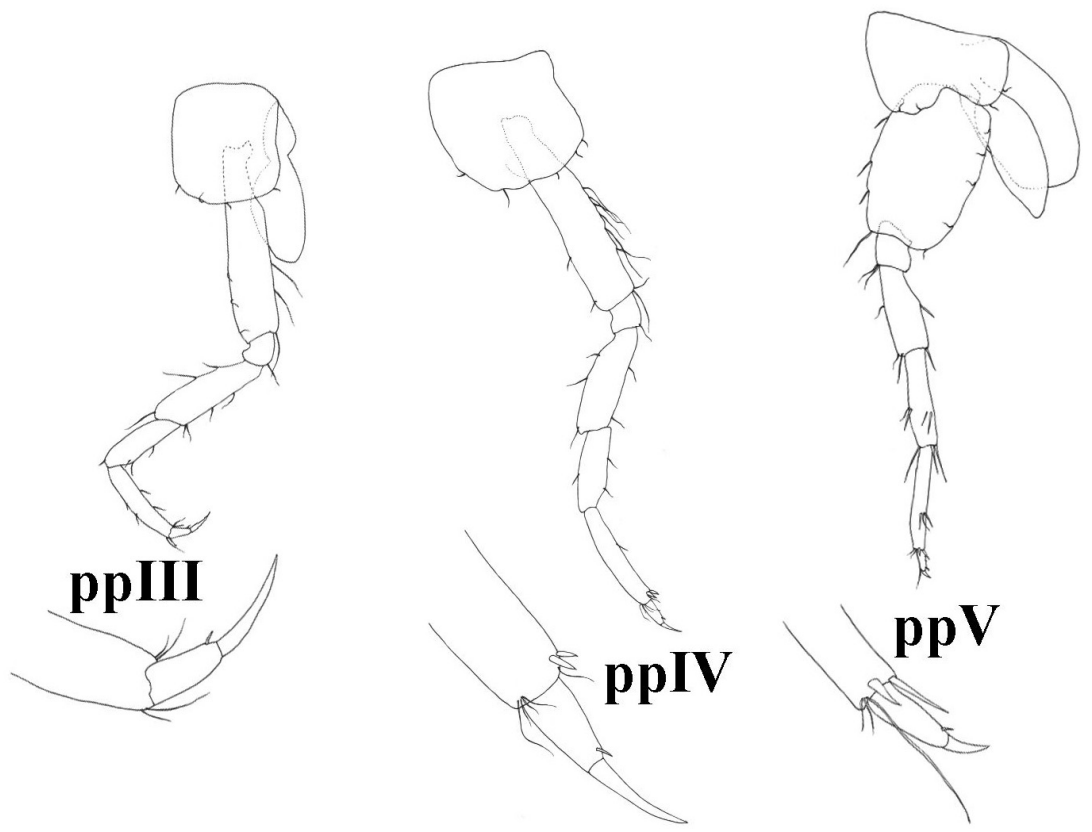

Figure I4. $N$. gebhardti, ppIII = pereopod III, ppIV = pereopod IV, ppV = pereopod V.

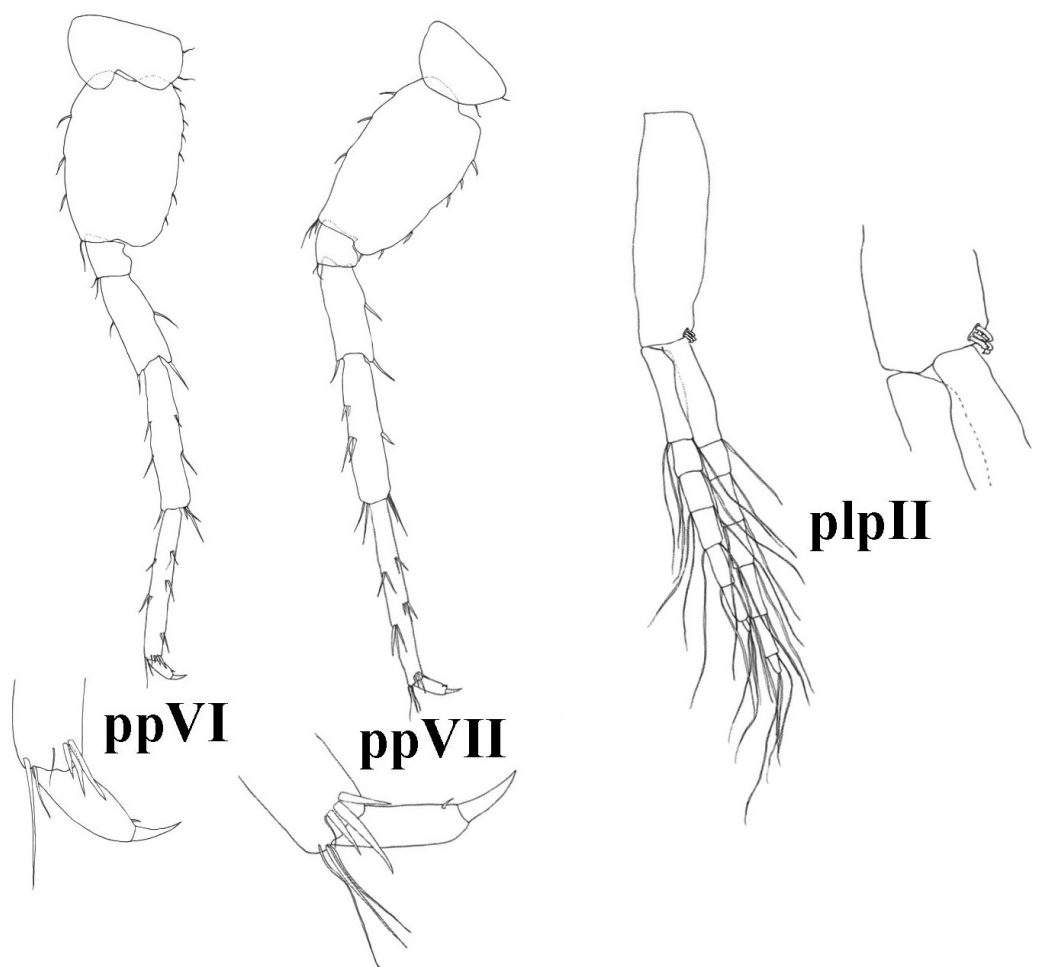

Figure I5. $N$. gebhardti, ppVI = pereopod VI, ppVII = pereopod VII, plpII = pleopod II 


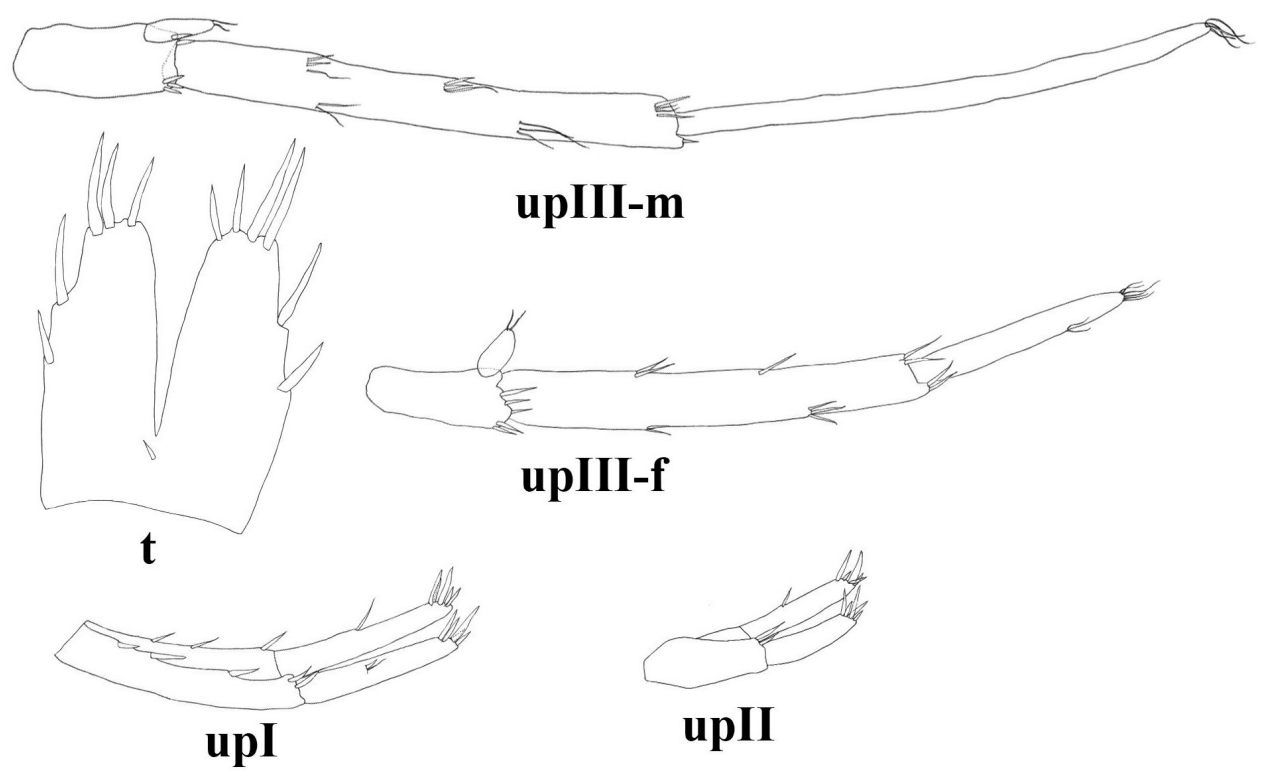

Figure 16. $N$. gebhardti, t: telson, upI: uropod I, upII: uropod II, upIII-m: male's uropod III, upIII-f: female's uropod III.

near the spine-like seta (sometimes not visible or absent). Additional spiniform setae on posterior margin are absent (Fig. 15).

Pleopods. Pleopods I-III with 3, rarely 4 hooked retinacles. Pleopod II rami of 11-13 articles each (Figs 11, 15).

Uropods. Uropod I basipododite with 4-5 dorso-lateral and 1-3 dorsomedial spiniform setae including spiniform setae in distal position. Length ratio endopodite: exopodite as 1.00: 0.91 (0.87-0.97); rami slightly curved. Endopodite with 1-2 setae, apically 5 spinifom setae. Exopodite with 1-4 setae or spines in 1-2 groups; apically 5 spinifom setae (Figs 11, 16).

Uropod II endopodite: exopodite length as 1.00: 0.84 (0.77-0.95) (Figs 11, 16).

Uropod III 38 (37-39)\% (males) and 26 (24-30)\% (females) of body length. Basipodite with 0-1 lateral setae and 5-6 apical spiniform and thin setae. Endopodite 41 (39-44)\% (males) and 48 (41-54)\% (females) of basipodite length; endopodite apically with $0-2$ thin-flexible and spiniform setae; laterally with $0-1$ seta. Exopodite of uropod III rod-shaped, distal article of exopodite 100 (95-105)\% (males) or $60(52-78) \%$ (females) of proximal article length. Proximal article with 3-4 groups of plumose, thin-flexible and spiniform setae along inner margin and 2-4 groups of thin-flexible and spiniform setae along outer margin. Distal article without lateral seta (males) or with 3 setae in 1 group (females); apically 4-7 setae (Figs 11, 16). 


\section{Comparison with phylogenetically related and geographically close species}

$N$. molnari and N. gebhardti share few main traits (the same body size class, slender body, sexually dimorphic uropod III but not uropod I), but differ from each other in the shape of epimeral plates, the size of gnathopod propodi, in denticulation of spines on outer lobe of maxilla I and in the number of retinacles (Angyal and Balázs 2013). Keeping these differences in mind we compare both species to the species that are either closely related according to molecular phylogeny, or to the species that live in the same geographic area.

Niphargus vadimi Birstein, 1961 is known from Crimea. Despite its close position suggested by the presented molecular tree, this species differs from phylogenetically related $N$. gebhardti and non-related $N$. molnari in considerably larger body size and much larger gnathopods.

High morphological similarity to the focal pair of species reveal another four species phylogenetically related to $N$. gebhardti, namely Niphargus bihorensis Schellenberg, 1940, Niphargus fongi Fišer \& Zagmajster, 2009, Niphargus carniolicus Sket, 1960, and Niphargus dobati Sket, 1999. Epikarstic N. bihorensis is known from Romania and Italy, whereas the latter three are known from epikarst and karst river beds from Slovenian caves. All four species share with focal species main traits (body size, slender body, sexually dimorphic uropod III but not uropod I).

$N$. bihorensis and $N$. fongi differ from the focal species in the shape of gills (being narrow instead of ovoid as in focal species) and in higher number of retinacles on pleopods. In addition, $N$. fongi differs from $N$. molnari and $N$. gebhardti by (i) the elevated number of setae along posterior margin of epimeral plate III, (ii) the longer apical telson spines, (iii) and the reduced number of denticulated spines in palmar corners of both gnathopods. $N$. bihorensis, which is a complex of at least two morphologically indistinguishable species (Meleg et al. 2013), differs from the focal species by (i) reduced number of spines on maxilla I outer lobe (only 6), (ii) more numerous setae on maxilla I palpus (7-8), (iii) and by more numerous retinacles.

$N$. carniolicus and $N$. dobati differ from the focal pair of species in the length of rami of uropod I (expopodite equal to or slightly longer than endopodite versus exopodite consistently shorter to endopodite in focal species). In addition, $N$. carniolicus differs from $N$. molnari and $N$. gebhardti by (i) shorter apical spines on telson, and (ii) fewer denticulated spines on palmar corner of gnathopods. $N$. dobati differs from the two focal species by (i) the elevated number of spines on uropod I basipodite, (ii) the length of pereopod V and VI (which are longer comparing with pereopod VII), and the (iii) elevated number of mandibular palp 'D seta'.

Phylogenetic relationship of $N$. molnari to the rest of Niphargus species is not clear, however a few morphologically similar species, like Niphargus schellenbergi S. Karaman, 1932 are known. It differs from $N$. molnari and $N$. gebhardti by (i) the differently ornamented telson (5-7 long apical spines and 2-5 lateral spines in N. schellenbergi, respectively), (ii) more numerous apical setae on uropod III endopodit, (iii) elevated number of pleopod retinaculi, (iv) by the length of uropod I exopodite, which 
is slightly longer than endopodit, (v) by several setae along outer margin of gnathopod dactyli, and (vi) by bigger body size (>10 $\mathrm{mm}$ ).

The following species are compared with $N$. molnari and $N$. gebhardti due to their geographical vicinity. Niphargus forroi G. Karaman, 1986 was described from Northeast Hungary, and is known from only a couple of caves from the Bükk Mts. Beside the close body size, $N$. forroi agree with $N$. molnari by the similar seta numbers and arrangement on the gnathopods, by the telson spine-pattern, as well as by the number of different spine and seta types on pereopod dactyli. $N$. forroi differs from $N$. molnari by (i) the subrounded posteroventral corner of the epimeral plates, (ii) the lower number of mandibular palp 'D setae' and by (iii) the reduced number of maxilla distal article apical seta. $N$. forroi differs from both $N$. molnari and $N$. gebhardti by the number of posterior margin setae on pereopods V-VII. The description of Niphargus hungaricus Méhely, 1937 (endemic species of the Köszegi Mts.) contains no drawings and not enough characters that would be needed for proper comparison. A later work of Méhely (1941) is only partially filling this gap by containing a drawing on the first gnathopod and some additional data on its seta arrangement. According to the available information, $N$. hungaricus differs from $N$. molnari and $N$. gebhardti by (i) the setae number of gnathopods dactyli outer margin (always more than 1 seta of $N$. hungaricus) and by (ii) the length of male's uropod I endopodite (inner ramus is elongated and two times long as outer ramus in $N$. hungaricus). There are different Niphargus populations in the Bükk Mts. and in the Aggtelek Karst belonging to the Niphargus tatrensis Wrzesniowsky, 1888 species group including Niphargus aggtelekiensis Dudich, 1932. Although the taxonomic status of these populations is not clear, the complex shares several distinct morphological characters that can be compared with the focal species. Populations of $N$. tatrensis - N. aggtelekiensis complex differ from N. molnari and $N$. gebhardti by (i) larger body size $(>15 \mathrm{~mm}$ ), (ii) the elevated number of setae along outer margin of gnathopods dactyli (there are more than one), (iii) the lower mandibular 'A' and 'D seta' number and (iv) the elongated distal article of uropod III of both gender. Main diagnostic characters are presented in Table 1.

\section{Molecular taxonomy}

Phylogenetic relationships within the genus Niphargus (Fig. 17) showed that the two redescribed species of Niphargus from Hungary are not phylogenetically closely related. Phylogenetic relationship of $N$. molnari to the rest of Niphargus species is unclear; species is nested within basal polytomy. N. gebhardti belongs to the clade of Central to Eastern European species. The focal species is in sister relationship with a pair of morphologically cryptic species endemic to Western Carpathian (N. bihorensis, see Meleg et al. 2013). Other closely related species include N. vadimi from Crimea, Pontoniphargus racovitzai from Eastern Romania and a clade of epikarstic and interstitial species from Southern Slovenia ( $N$. fongi, $N$. carniolicus, $N$. wolf $i$ and $N$. dobati). 


\begin{tabular}{|c|c|c|c|c|c|c|c|c|c|c|c|}
\hline 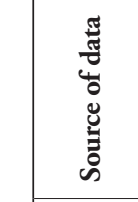 & $\begin{array}{l}\frac{\tilde{y}}{0.0} \\
\bar{w} \\
\tilde{5} \\
0\end{array}$ & $\begin{array}{l}\frac{\tilde{u}}{0.0} \\
\bar{w} \\
\tilde{n} \\
0\end{array}$ & 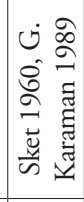 & 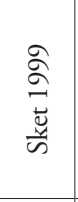 & 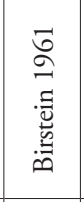 & 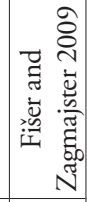 & 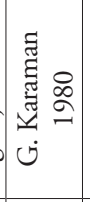 & 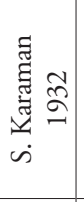 & 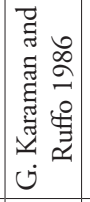 & 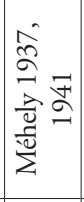 & 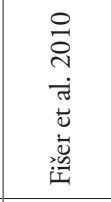 \\
\hline 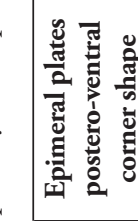 & 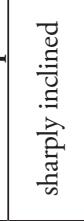 & 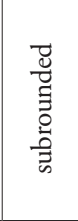 & 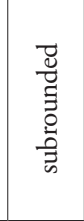 & 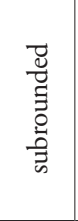 & 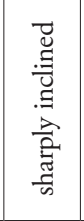 & 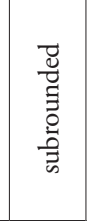 & 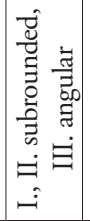 & $\begin{array}{l}\overrightarrow{\tilde{u}} \\
\vec{\Xi} \\
\overline{0} \\
\overrightarrow{\tilde{n}}\end{array}$ & $\begin{array}{l}\overrightarrow{\vec{v}} \\
\vec{\Xi} \\
\overline{0} \\
\overrightarrow{\tilde{z}}\end{array}$ & 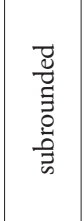 & 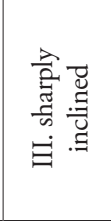 \\
\hline 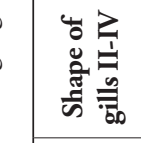 & $\begin{array}{l}70 \\
0 \\
0\end{array}$ & $\begin{array}{l}\overline{0} \\
\bar{\partial} \\
0\end{array}$ & n. & 苞 & n. & 总 & 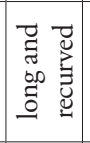 & n. & 栉 & $n$. & 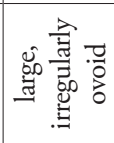 \\
\hline 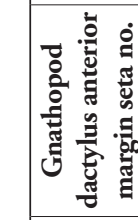 & $\begin{array}{l}\frac{0}{b 0} \\
\frac{E}{6}\end{array}$ & $\begin{array}{l}\frac{0}{b 0} \\
\frac{\vec{b}}{6}\end{array}$ & $\begin{array}{l}\frac{0}{60} \\
. \\
\frac{5}{\omega}\end{array}$ & $\begin{array}{l}\frac{\omega}{b 0} \\
\frac{E}{6}\end{array}$ & n. & $\begin{array}{l}\frac{0}{b 0} \\
. \frac{5}{\omega}\end{array}$ & $\begin{array}{l}\frac{0}{60} \\
.\end{array}$ & 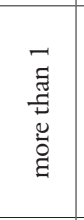 & $\begin{array}{l}\frac{0}{00} \\
. \\
\frac{5}{5}\end{array}$ & 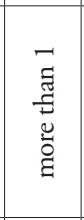 & 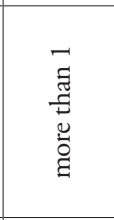 \\
\hline 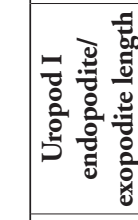 & 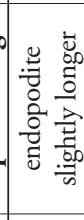 & 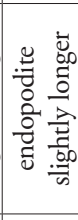 & 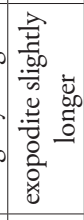 & 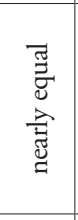 & $n$. & 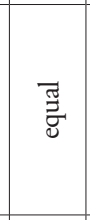 & 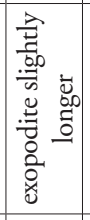 & 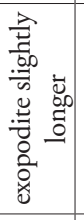 & 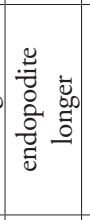 & 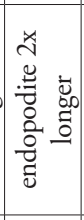 & 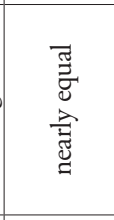 \\
\hline 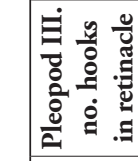 & $N$ & 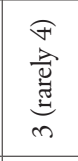 & $\mathfrak{f}$ & $\stackrel{+1}{m}$ & $\sim$. & i & $\downarrow$ & $\begin{array}{l}0 \\
1 \\
m\end{array}$ & $\sim$ & $n$. & $N$ \\
\hline 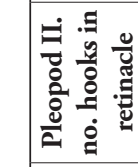 & $\sim$ & 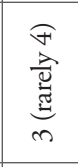 & if & $\stackrel{+}{+}$ & n. & $\tilde{n}$ & $\downarrow$ & $\hat{n}$ & N & n. & $\sim$ \\
\hline 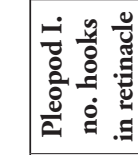 & $\sim$ & 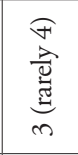 & $\mathfrak{f}$ & m & n. & I & I & $\downarrow$ & N & $n$. & N \\
\hline 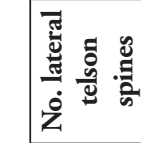 & $\stackrel{\oplus}{\perp}$ & I & I & $\sim$ & $n$ & $\stackrel{I}{I}$ & 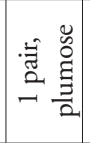 & $\stackrel{n}{\sim}$ & N & $\stackrel{I}{I}$ & $\tilde{1}$ \\
\hline 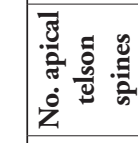 & $y_{m}^{+}$ & $\begin{array}{l}p \\
m\end{array}$ & $i$ & $\stackrel{+}{m}$ & n. & $\stackrel{n}{n}$ & î & in & $N$ & $\stackrel{n}{n}$ & $\underset{m}{+1}$ \\
\hline $\begin{array}{l}\stackrel{\mathscr{u}}{u} \\
\text { के }\end{array}$ & 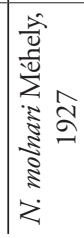 & 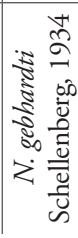 & 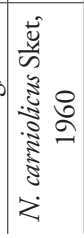 & 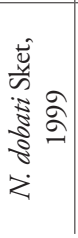 & 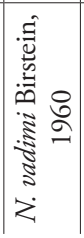 & 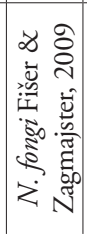 & 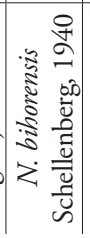 & 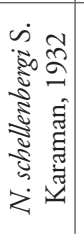 & 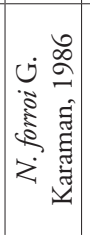 & 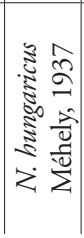 & 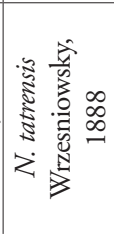 \\
\hline
\end{tabular}




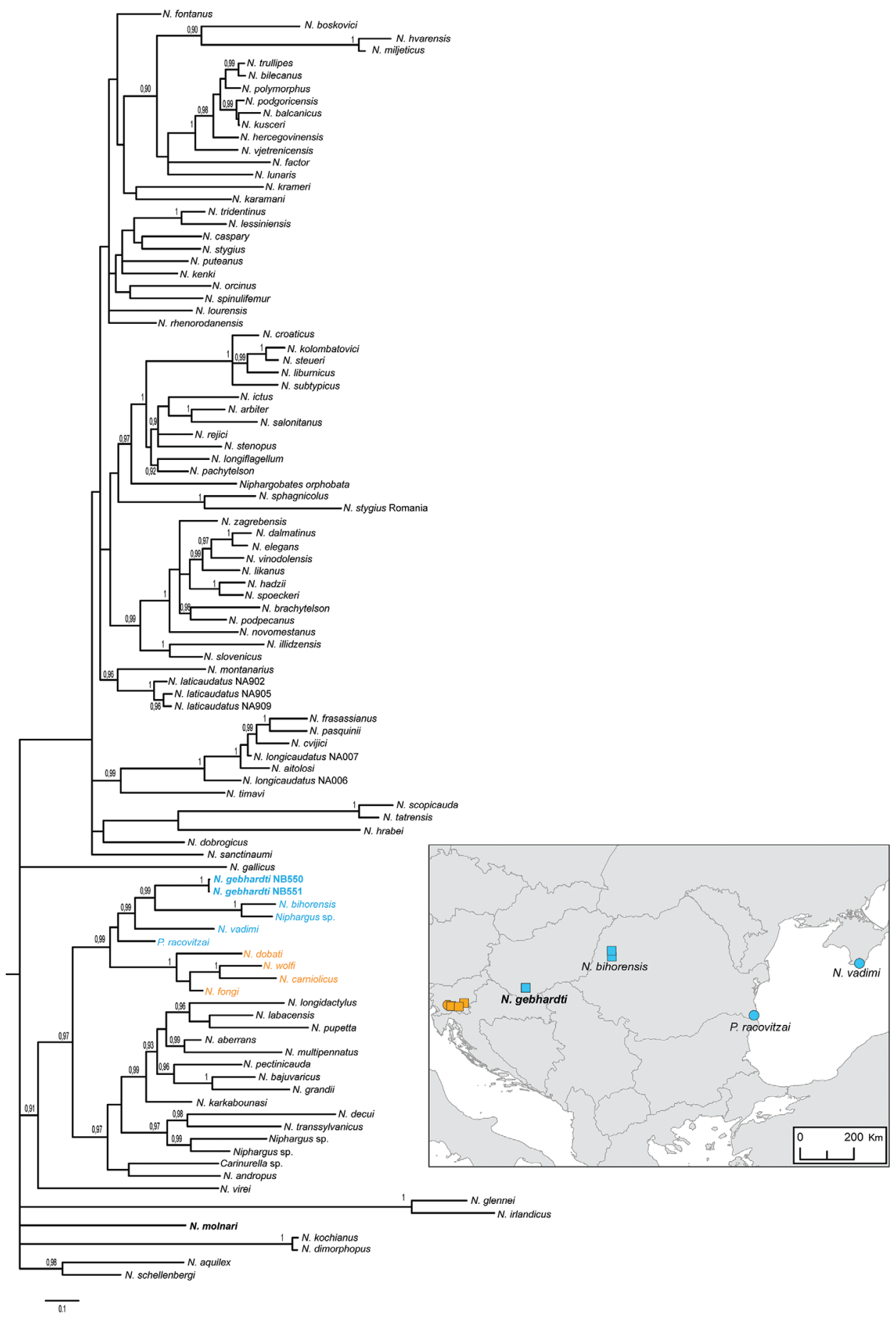

Figure 17. Bayesian phylogenetic tree of 104 amphipod taxa (including $N$. molnari and $N$. gebhardti) based on COI, $28 \mathrm{~S}$ and histone (H3) sequences. Map represents distribution of the clade with $N$. gebharti. Squeres represent epikarstic species and circles species from other subterranean habitats. 


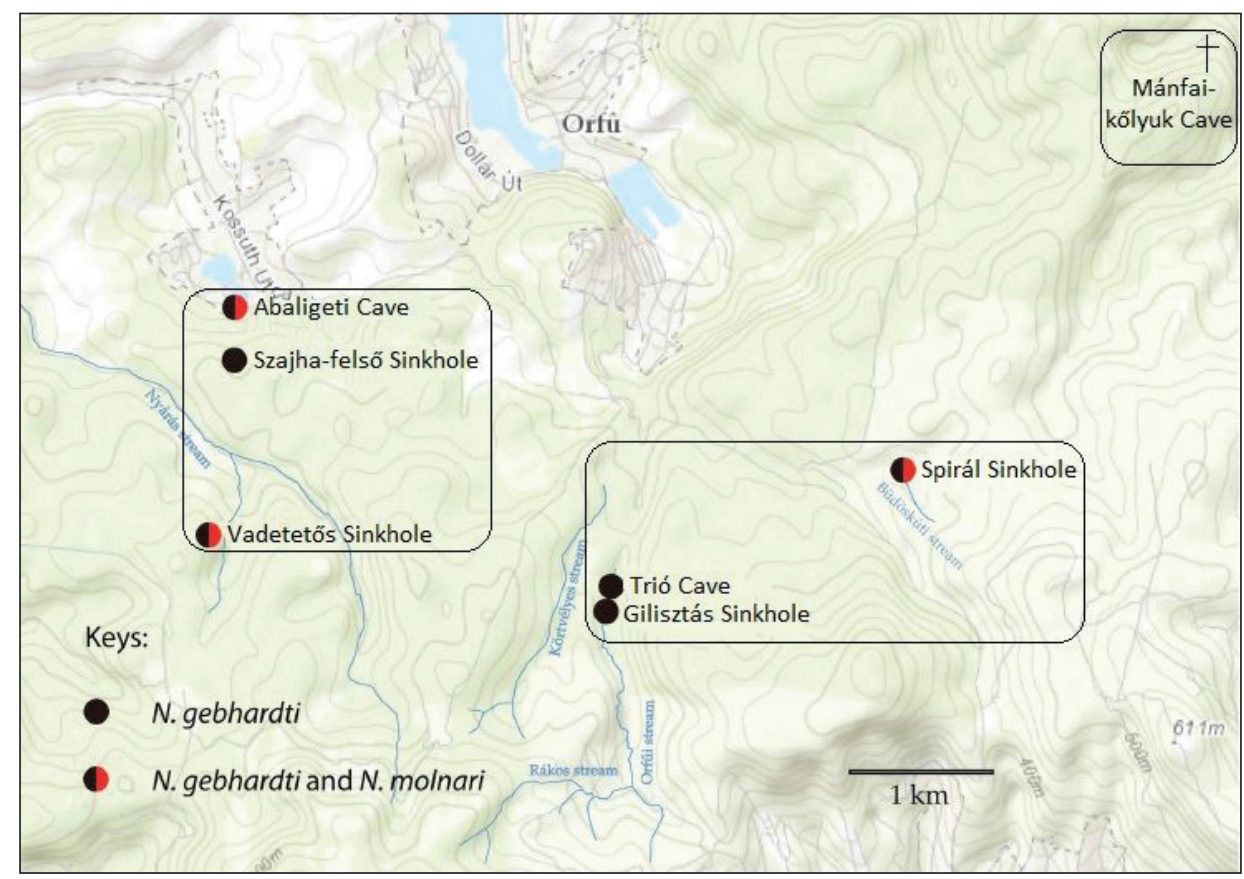

Figure I 8. Distribution of $N$. molnari and N. gebhardti within the Western Mecsek.

\section{Remarks on ecology and distribution}

Among the studied two species, $N$. gebhardti was collected more frequently, as it was found in five other caves of the Western Mecsek in addition to the type locality, namely Trió Cave, Gilisztás Sinkhole, Szajha-felső Sinkhole, Vadetetős Sinkhole and Spirál Sinkhole (Fig. 18). In most of these, two types of water bodies exist: i) small pools of residual- or percolated/dripping water and ii) streams or minor streaming water. Amount of water in the caves is dependent on the rainfall in the surface. In all six caves, $N$. gebhardti specimens were found in isolated, shallow pools in limestone, sinter or clay, most likely formed by dripping water (Fig. 19). Specimens were never observed in streams or any other streaming waters. During our repeated visits between 2010 and 2013 (altogether 24 visits in the 6 caves), the same pools were checked every time and some specimens were always found in them (except when the pools dried out). Once it was observed that a group of $N$. gebhardti (approximately 20 specimens) were fed upon a dead Oxychilus snail in a pool.

$N$. molnari was observed in the Abaligeti Cave and in two sinkholes that the other species (N. gebhardti) was also inhabited, Spirál Sinkhole and Vadetetős Sinkhole (Fig. 18). Density of $N$. molnari was high in the stream of the Western 2 collateral of the Abaligeti Cave, however in the other two caves only a few specimens were found in streaming water, always in deeper parts of the caves. The two species were always spatially well segregated. In the Abaligeti Cave $N$. molnari coexisted with Protelsonia hungarica Méhely, 1924 (endemic aquatic troglobiont isopod of the cave) and with the troglomorph specimens of Gammarus fossarum Koch, 1836. 


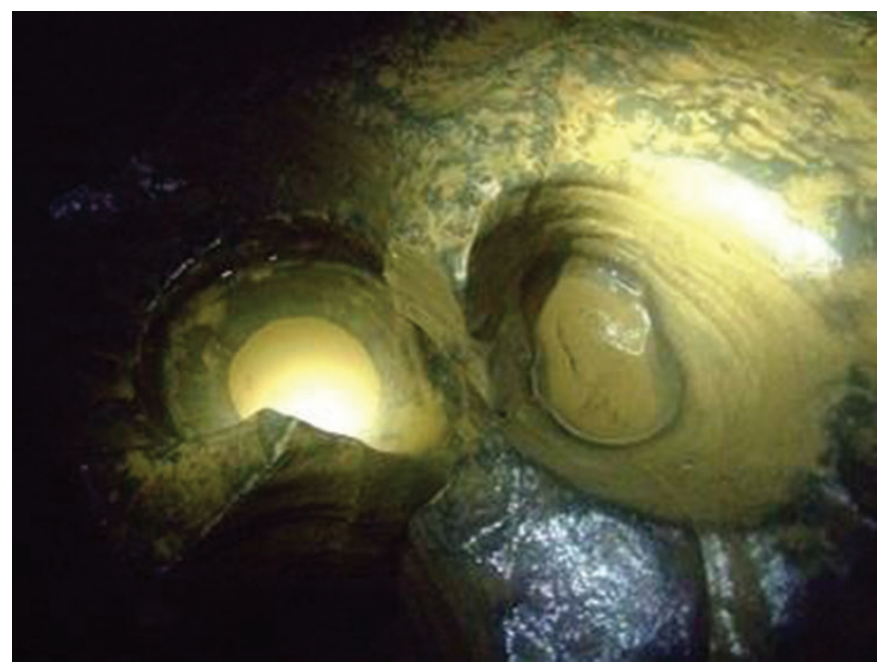

Figure 19. Small pool formed by dripping water, one of the occupied microhabitats of $N$. gebhardti in the Trió Cave.

\section{Discussion}

Due to its protected geographical situation, since the Tertiary, the area of Mecsek may have played a refugial role during the alternating warmer and colder eras, preserving old lineages of Crustaceans. They presumably ensconced into subterranean aquatic habitats from searing creaks of the Paratethys Sea, that encompassed the islands of the Mecsek. Then, by degress, they had been adapted to the subterranean conditions in both physiological and morphological features (Méhely 1925). According to results of our phylogenetic analysis, $N$. molnari and $N$. gebhardti represent completely distinct lineages, which colonized the Mecsek area independently. The two species are spatially segregated within the same caves. $N$. gebhardti inhabits isolated pools of stagnant water, which fed by percolating water from the limestone fissures, so called epikarst. Interestingly $N$. gebhardti is apparently phylogenetically related to epikarstic species from Slovenia. On the contrary, N. molnari was always found in streaming waters.

The distribution range of the two endemic species is small, the most distant caves are seven kilometers far. These caves belong to three different catchment areas (Fig. 18). Despite of our repeated visits and careful searching, Niphargus specimens were not found in the Mánfai-kőlyuk Cave. N. molnari supposedly has gone extinct in its type locality as it is ruined due to the industrial utilization of the cave (Angyal 2012). Moreover, the type locality of $N$. gebhardti - which is a touristic cave with 80.000 annual visitors - may be also endangered. Considering the extremely narrow distributional range of the two species and the vulnerability of their populations, $N$. molnari and N. gebhardti are suggested to be placed into the 'Vulnerable (VU)' 
category according to the following criteria of IUCN Red List of Threatened Species (IUCN 2012): i) number of locations is $\leq 10$ ('B2') and ii) area of occupancy is less than $20 \mathrm{~km}^{2}$ ('D2').'

Hidrologically connected caves are in quadrats.

\section{Conclusions}

Some highly endemic, troglobiont invertebrate taxa are known from the Southern Hungarian Mecsek Mts. Two of them, the blind amphipod Niphargus molnari Méhely, 1927 and Niphargus gebhardti Schellenberg, 1934 have been rediscribed, applying the modern approach of integrative taxonomy. Comparative scanning electron microscopy used for first time on niphargids, and it proved to be a rather useful method in analysing and illustrating of barely visible diagnostic characters. As contributions to the future molecular genetic studies on niphargids, cytochrome c oxidase subunit I (COI) sequences as barcodes of $N$. molnari and $N$. gebhardti are now available for the public. The phylogenetic analyses have shown that the two species - which are spatially segregated in caves where they coexist - represent completely distinct lineages and may have colonized the Mecsek area independently. Phylogenetic relationship of $N$. molnari to the rest of Niphargus species is for the present not clear. $N$. gebhardti is closely related to a clade of epikarstic species from Southern Slovenia and to cryptic species endemic to Western Carpathians. New localities of both species have been found. The two species are suggested for legal protection, they should be listed into 'Vulnerable' category of the IUCN Red List of Threatened Species.

\section{Acknowledgements}

Professional trips of DA and GB to the Biotechnical Faculty of University of Ljubljana were funded by the Balassi Institute, Campus Hungary Short Therm Study Program (grants B2/1R/1411 and B2/1R/10676). VZ and CF were partially funded by Slovenian Research Agency Program P1-0184. We are grateful to Teo Delić (University of Ljubljana) and Mária Tuschek (Molecular Taxonomic Laboratory, Hungarian Natural History Museum) for their help in molecular taxonomic work. Dr. László Forró, Katalin Kovács and Dr. László Dányi (Department of Zoology, HNHM) are also acknowledged for providing literature and infrastructure for our studies. Dr. Krisztina Buczkó (Department of Botany, HNHM) is gratefully acknowledged for her help in scanning electron microscopy. Our thanks are due to speleologist colleagues from the Pro Natura Karst and Cave Research Society, namely Andrea Illés, Zoltán Tegzes, Artúr Nyírő and Béla Nacsa for their help during the sample collections. We are grateful to Dr. Jenő Kontschán (Plant Protection Institute, Hungarian Academy of Sciences) for his advices regarding the early phase of the manuscript. Gabriella Koltai is acknowledged for the 
linguistic checking of the manuscript. We also thank Dr. John Holsinger, Dr. Ronald Vonk and Dr. Oliver Coleman for their helpful and constructive commentaries that remarkably improved the early version of the manuscript.

\section{References}

Angyal D (2012) Invertebrate fauna of the Mánfai-kőlyuk Cave (Mecsek, SW Hungary) in the light of utilization by waterworks - previous results. Természetvédelmi Közlemények 18: 24-33. [In Hungarian]

Angyal D, Balázs G (2013) Distinguishing characters of Niphargus gebhardti Schellenberg, 1934 and Niphargus molnari Méhely, 1927 (Crustacea: Amphipoda): a clarification. Opuscula Zoologica, Budapest 44(1): 3-8.

Birstein JA (1961) Subterranean Amphipodes of the Crimea. Biospeologica Sovietica. XIV. Boljeten Moskovskogo občestva ispitateljev prirodi 66(6): 126-144.

Colgan DJ, Ponder WF, Eggler PE (2000) Gastropod evolutionary rates and phylogenetic relationships assessed using partial 28S rDNA and histone $\mathrm{H} 3$ sequences. Zoologica Scripta 29(1): 29-63.

Dezső J (2011) A dél-dunántúli karsztos területek morfológiai, üledékföldtani vizsgálata és összehasonlító értékelésük analóg képződményekkel. PhD thesis, University of Pécs, Pécs, Hungary. [In Hungarian]

Dudich E (1941) Die im Gebiete des historischen Ungarn nachgewiesenen Amphipoden. Fragmenta Faunistica Hungarica 4(1-4): 14-20. [In German]

Fišer C, Zagmajster M (2009) Cryptic species from cryptic space: the case of Niphargus fongi sp. n. (Amphipoda, Niphargidae). Crustaceana 82(5): 593-614.

Fišer C, Coleman CO, Zagmajster M, Zwittnig B, Gerecke R, Sket B (2010) Old museum samples and recent taxonomy: a taxonomic, biogeographic and conservation perspective of the Niphargus tatrensis species complex (Crustacea: Amphipoda). Organisms Diversity \& Evolution 10: 5-22.

Fišer C, Trontelj P, Luštrik R, Sket B (2009) Towards a unified taxonomy of Niphargus (Crustacea: Amphipoda): a review of morphological variability. Zootaxa 2061: 1-22.

Folmer O, Black M, Hoeh W, Lutz R, Vrijenhoek R (1994) DNA primers for amplification of mitochondrial cytochrome c oxidase subunit I from diverse metazoan invertebrates. Molecular Marine Biology and Biotechnology 3: 294-299.

Gebhardt A (1933) Vergleichung der Tierwelt der Abaligeter - und Mánfaer Höhlen. Állattani Közlemények 30(1-2): 36-44. [In Hungarian and German]

Gebhardt A (1934) Az Abaligeti barlang élővilága. Mathematikai és Temészettudományi Közlemények 37: 1-264. [In Hungarian]

Gebhardt A (1963) A Mecsek hegység barlangjainak biológiai vizsgálata. Janus Pannonius Múzeum Évkönyve 8: 5-32. [In Hungarian]

Gebhardt A (1967) A Mecsek hegység állatvilágának térbeli elterjedése élőhelyek szerint. Janus Pannonius Múzeum Évkönyve 12: 7-14. [In Hungarian] 
Hou Z, Sket B, Li S (2013) Phylogenetic analyses of Gammaridae crustacean reveal different diversification patterns among sister lineages in the Tethyan region. Cladistics 30: 352-365.

IUCN (2012) IUCN Red List Categories and Criteria: Version 3.1. Second edition. IUCN, Gland, Switzerland and Cambridge, UK, iv + 32 pp. doi: 10.1111/cla.12055

Karaman S (1932) 5. Beitrag zur Kenntnis der Süsswasser-Amphipoden (Amphipoden unterirdischer Gewässer). Prirodoslovne razprave, Ljubljana 2: 179-232. [In German]

Karaman GS (1980) First discovery of Niphargus bihorensis Schell. 1940 (fam. Gammaridae) in Italy with remarks to $\mathrm{N}$ elegans Garb. 1894. (Contribution to the knowledge of the Amphipoda 111). Glas. Repub. Zavoda Zašt. Prir.- Prir. Muz. Titograd 13: 71-80.

Karaman GS, Ruffo S (1986) Amphipoda: Niphargus - group (Niphargidae sensu Bousfield, 1982). In: Botosaneau L (Ed.) Stygofauna mundi, a faunistic, distributional, and ecological synthesis of the world fauna inhabiting subterranean waters (including marine interstitial), 514-534.

Karaman G (1989) The redescription of Niphargus carniolicus Sket 1960 (fam. Niphargidae) with remarks to its new taxonomic position (Contribution to the knowledge of the Amphipoda 195). Poljepriveda i Šumarstvo 35: 13-28.

Katoh K, Standley DM(2013) MAFFT multiple sequence alignment software version 7: improvements in performance and usability. Molecular Biology and Evolution 30: 772-780.

Keane TM, Creevey CJ, Pentony MM, Naughton TJ, McInerney JO (2006) Assessment of methods for amino acid matrix selection and their use on empirical data shows that ad hoc assumptions for choice of matrix are not justified. BMC Evolutionary Biology 6: 29. doi: 10.1186/1471-2148-6-29

Mamos T, Wattier R, Majda A, Sket B, Grabowski M (2014) Morphological vs. molecular delineation of taxa across montane regions in Europe: The case study of Gammarus balcanicus Schäferna, 1922 (Crustacea: Amphipoda). Journal of Zoological Systematics \& Evolutionary Research 52(3): 237-248.

Meleg IN, Zakšek V, Fišer C, Kelemen BS, Moldovan OT (2013) Can environment predict cryptic diversity? The case of Niphargus inhabiting Western Carpathian groundwater. PLoS ONE 8(10): e76760. doi: 10.1371/journal.pone.0076760

Méhely L (1925) Ein Lebendes Fossil. (Protelsonia hungarica, nov. gen., n. sp., Ein blinder Isopode aus Ungarn.) Matematikai és Természettudományi Értesítő 41: 185-192. [In Hungarian and German]

Méhely L (1927) Új férgek és rákok a magyar faunában. Neue Würmer und Krebse aus Ungarn, Budapest 1927: 1-19. [In Hungarian and German]

Méhely L (1937) Niphargus hungaricus ein neuer Amphipode aus Ungarn. Zoologischer Anzeiger 120: 117-119.

Méhely L (1941) A Niphargus-kutatás új útjai. Neue Wege der Niphargus-Forschung. Budapest 1941: 1-36. [In Hungarian and German]

Miller MA, Holder MT, Vos R, Midford PE, Liebowitz T, Chan L, Hoover P, Warnow T (2012) The CIPRES portals CIPRES. http://www.phylo.org/sub_sections/portal

Padial JM, Miralles A, De la Riva I, Vences M (2010) The integrative future of taxonomy. Frontiers in Zoology 7: 16. doi: 10.1186/1742-9994-7-16 
Ronquist F, Huelsenbeck JP (2003) MrBayes 3: Bayesian phylogenetic inference under mixed models. Bioinformatics 19: 1572-1574.

Schellenberg A (1933) Weitere deutsche und ausländische Niphargiden. Zoologischer Anzeiger 102: 22-23. [In German]

Schellenberg A (1934) Amphipoden aus Quellen, Seen und Höhlen. Zoologischer Anzeiger 106: 200-209. [In German]

Schellenberg A (1935) Schlüssel der Amphipodengattung Niphargus mit Fundortangaben und mehreren neuen Formen. Zoologischer Anzeiger 111: 204-211. [In German]

Sket B (1960) Einige neue Formen der Malacostraca aus Jugoslawien III. Bulletin Scientifique 5(5): 73-75. [In German]

Sket B (1999) Niphargus aquilex dobati ssp. n. (Crustacea) from the karst of Slovenia. Mitteilungen des Verbandes der deutschen Höhlen- und Karstforscher 45(2): 54-56.

Švara V, Delić T, Rada T, Fišer C (submitted) Molecular phylogeny of Niphargus boskovici (Crustacea: Amphipoda) reveals a new species from epikarst.

Verovnik R, Sket B, Trontelj P (2005) The colonization of Europe by the freshwater crustacean Asellus aquaticus (Crustacea: Isopoda) proceeded from ancient refugia and was directed by habitat connectivity. Molecular Ecology 14: 4355-4369.

Zakšek V, Sket B, Trontelj P (2007) Phylogeny of the cave shrimp Troglocaris: evidence of a young connection between Balkans and Caucasus. Molecular Phylogenetics and Evolution 42: 223-235. 


\section{Supplementary material I}

\section{Protocols and thermo profiles used in molecular studies}

Authors: Dorottya Angyal, Gergely Balázs, Valerija Zakšek, Virág Krízsik, Cene Fišer

Data type: Primers, molecular protocols

Copyright notice: This dataset is made available under the Open Database License (http://opendatacommons.org/licenses/odbl/1.0/). The Open Database License $(\mathrm{ODbL})$ is a license agreement intended to allow users to freely share, modify, and use this Dataset while maintaining this same freedom for others, provided that the original source and author(s) are credited.

\section{Supplementary material 2}

\section{List of taxa and sequence data used in phylogenetic analysis}

Authors: Dorottya Angyal, Gergely Balázs, Valerija Zakšek, Virág Krízsik, Cene Fišer Data type: Sequence data

Copyright notice: This dataset is made available under the Open Database License (http://opendatacommons.org/licenses/odbl/1.0/). The Open Database License $(\mathrm{ODbL})$ is a license agreement intended to allow users to freely share, modify, and use this Dataset while maintaining this same freedom for others, provided that the original source and author(s) are credited.

\section{Supplementary material 3}

\section{Original descriptions of $N$. molnari and $N$. gebhardti}

Authors: Dorottya Angyal, Gergely Balázs, Valerija Zakšek, Virág Krízsik, Cene Fišer Data type: Descriptions

Copyright notice: This dataset is made available under the Open Database License (http://opendatacommons.org/licenses/odbl/1.0/). The Open Database License $(\mathrm{ODbL})$ is a license agreement intended to allow users to freely share, modify, and use this Dataset while maintaining this same freedom for others, provided that the original source and author(s) are credited. 